\title{
Predatory behaviour of some Central European pselaphine beetles (Coleoptera: Staphylinidae: Pselaphinae) with descriptions of relevant morphological features of their heads
}

\author{
AndRea SCHOMANN ${ }^{1}$, Kerstin AFFLERBACH${ }^{2}$ and Oliver BETZ ${ }^{3}$ \\ ${ }^{1}$ Natural History Museum of Denmark/University of Copenhagen, Zoological Museum, Universitetsparken 15, DK-2100 \\ Copenhagen, Denmark; e-mail: aschomann@snm.ku.dk; andrea.schomann@web.de \\ ${ }^{2}$ Eichenstraße 8, 56305 Puderbach, Germany; e-mail: kerstin.afflerbach@web.de \\ ${ }^{3}$ Universität Tübingen, Zoologisches Institut, Abteilung für Evolutionsbiologie der Invertebraten, Auf der Morgenstelle 28E, \\ D-72076 Tübingen, Germany; e-mail: oliver.betz@uni-tuebingen.de
}

Key words. Staphylinidae, Pselaphinae, Brachygluta, Bryaxis, Bythinus, Pselaphus, Rybaxis, Tyrus, predatory behaviour, prey-capture, morphology, head, antenna, mouthparts, maxillary palp, sensillum, sensory organ

\begin{abstract}
The Pselaphinae is a large subfamily of staphylinid beetles with a characteristic habitus and small body size. Detailed morphological and behavioural studies on these beetles are scarce. In this study, specimens of Bryaxis puncticollis (Denny, 1825), Bryaxis bulbifer (Reichenbach, 1816), Bythinus burrelli (Denny, 1825), Brachygluta fossulata (Reichenbach, 1816), Rybaxis longicornis (Leach, 1817), Pselaphus heisei (Herbst, 1792) and Tyrus mucronatus (Panzer, 1803), all collected in Northern Germany, have been examined with regard to their sensory organs (eyes and antennae), mouthparts and method of capturing prey. Scanning electron microscope studies revealed sex-specific differences in the numbers of ommatidia in Bryaxis puncticollis. A multitude of different sensilla on the antennae and great differences in the shape of the mouthparts were observed and peculiarities of the antennae and maxillary palps (e.g., the segment-like appendage) were examined using scanning and transmission electron microscopy. The prey-capture behaviour of these species is described in detail for the first time based on laboratory experiments using Heteromurus nitidus (Templeton, 1835) (Collembola) as prey. This behaviour seems to be tribe specific, ranging from simple seizure with the mandibles (e.g., Rybaxis longicornis, tribe Brachyglutini) to the employment of raptorial legs (Tyrus mucronatus, tribe Tyrini). The two Bryaxis species (tribe Bythinini) even employ their apparently sticky maxillary palps to capture prey. The assumption that a viscous secretion is used by these species is supported by the finding of glandular structures in the interior of their maxillary palps. Prey-capture is preceded by a complicated preparation phase in most of the species and followed by a sequence of preyhandling movements that seem to be adapted to restrain prey such as Collembola. In simple prey-choice experiments the beetles of several species preferred small prey, irrespective of their own body size. In these experiments, Bryaxis bulbifer and Brachygluta fossulata were more successful in capturing prey than Bryaxis puncticollis and Pselaphus heisei. This might be related to their different sensory equipment and different methods of capturing prey.
\end{abstract}

\section{INTRODUCTION}

The Pselaphinae is a globally distributed and very diverse subfamily of the beetle family Staphylinidae, comprising 9267 described species (A.F. Newton, pers. comm.). They are small predators $(0.5-5.5 \mathrm{~mm}$ in body length) with a characteristic appearance. They possess compound eyes with only a few ommatidia. The mouthparts are prognathous, often with prominent maxillary palps and strong mandibles, indicative of a predatory life style. Saprophagy is recorded from some species of the genera Batrisodes, Claviger and Adranes, but not mycoor phytophagy (Thayer, 2005).

Pselaphinae are most species-rich and diverse in the tropics, but also abundant in temperate regions. They usually occur in moist forest leaf litter or debris, or moist mosses at the margin of water bodies. Some pselaphines display unusual biological adaptations (e.g., myrmecophily), which sometimes also involve interesting behavioural features (especially remarkable in Claviger testaceus: Cammaerts, 1991).
Research on pselaphines has mostly focused on their systematics and geographical distribution, whereas studies on their behaviour (De Marzo, 1985, 1986, 1988; Engelmann, 1956; Poggi, 1990) and ecology (Reichle, 1967) are scarce. Furthermore, there are only a few general morphological studies on this group (e.g., Chandler, 2001; Jeannel, 1950; Sabella et al., 1998; Thayer, 2005). Most of the morphological data on Pselaphinae are general taxonomic morphological descriptions, often with notes on the conspicuous structures used for identification.

The aim of this publication is to extend the knowledge on the behaviour and morphology of Pselaphinae by examining several Central European species. Detailed information on the way that adult pselaphines catch and handle their prey, and comparative descriptions of the morphology of their sensory organs and mouthparts are provided. It was examined whether different speciesspecific strategies or structures are used in this process. Although the assembled information is limited, we attempt to establish correlations between certain aspects 
TABLE 1. Pselaphine species investigated in the present study (classification into tribes according to Löbl \& Besuchet, 2004) (+= studied, $-=$ not studied, $(+)=$ partly studied).

\begin{tabular}{|c|c|c|c|c|c|c|c|}
\hline $\begin{array}{l}\text { Tribe } \\
\text { (Supertribe) }\end{array}$ & Genus & Species & $\begin{array}{c}\text { Prey-capture } \\
\text { behaviour }\end{array}$ & $\begin{array}{c}\text { Prey-capture } \\
\text { success and prey } \\
\text { size preference }\end{array}$ & $\begin{array}{c}\text { Morphology } \\
\text { of eyes }\end{array}$ & $\begin{array}{c}\text { General } \\
\text { morphology } \\
\text { of antennae }\end{array}$ & $\begin{array}{l}\text { Morphology } \\
\text { of mouthparts }\end{array}$ \\
\hline \multirow[t]{3}{*}{$\begin{array}{l}\text { Bythinini } \\
\text { (Goniaceritae) }\end{array}$} & $\begin{array}{c}\text { Bryaxis } \\
\text { Kugelann, } 1794\end{array}$ & $\begin{array}{c}\text { puncticollis } \\
\text { (Denny, 1825) }\end{array}$ & + & + & + & + & + \\
\hline & & $\begin{array}{c}\text { bulbifer } \\
\text { (Reichenbach, 1816) }\end{array}$ & + & + & + & + & + \\
\hline & $\begin{array}{c}\text { Bythinus } \\
\text { Leach, } 1817\end{array}$ & $\begin{array}{c}\text { burrelli } \\
\text { Denny, } 1825\end{array}$ & - & - & - & $\begin{array}{c}(+) \text { structural } \\
\text { peculiarities }\end{array}$ & - \\
\hline \multirow[t]{2}{*}{$\begin{array}{l}\text { Brachyglutini } \\
\text { (Goniaceritae) }\end{array}$} & $\begin{array}{l}\text { Brachygluta } \\
\text { Thomson, } 1859\end{array}$ & $\begin{array}{c}\text { fossulata } \\
\text { (Reichenbach, 1816) }\end{array}$ & + & + & + & + & + \\
\hline & $\begin{array}{c}\text { Rybaxis } \\
\text { Saulcy, } 1876\end{array}$ & $\begin{array}{l}\text { longicornis } \\
\text { (Leach, 1817) }\end{array}$ & + & - & + & + & + \\
\hline $\begin{array}{l}\text { Pselaphini } \\
\text { (Pselaphitae) }\end{array}$ & $\begin{array}{c}\text { Pselaphus } \\
\text { Herbst, } 1792\end{array}$ & $\begin{array}{c}\text { heisei } \\
\text { Herbst, } 1792\end{array}$ & + & + & + & + & + \\
\hline $\begin{array}{l}\text { Tyrini } \\
\text { (Pselaphitae) }\end{array}$ & $\begin{array}{c}\text { Tyrus } \\
\text { Aubé, } 1833\end{array}$ & $\begin{array}{c}\text { mucronatus } \\
\text { (Panzer, 1803) }\end{array}$ & + & - & $\begin{array}{l}(+) \text { number } \\
\text { of ommatidia }\end{array}$ & - & $\begin{array}{l}(+) \text { maxillary } \\
\text { palps }\end{array}$ \\
\hline
\end{tabular}

of behaviour and particular morphological traits. The observations and conclusions are discussed in the context of earlier observations made by Engelmann (1956).

\section{MATERIAL AND METHODS}

Adult male and female beetles were collected in wet habitats mostly around the city of Kiel (Schleswig-Holstein, Northern Germany) by searching the ground litter at the margins of water bodies using a Reitter's sieve or "sifter".

The animals were transferred in small containers $(4.5 \mathrm{~cm}$ in diameter) with a floor of moist plaster of Paris, and kept at $14-20^{\circ} \mathrm{C}$ in an outdoor shelter. The insects were maintained on a diet of small collembolans [Heteromurus nitidus (Templeton, 1835)]. The photoperiodic conditions were that of natural day length.

The specimens examined (in all 144) belong to 7 species in 6 genera, representing four tribes in two supertribes (Table 1). The smallest were Bryaxis puncticollis, Bryaxis bulbifer and Bythinus burrelli, all around $1.3 \mathrm{~mm}$ in length (from base of labrum to abdominal tip). These have maxillary palps with a voluminous fourth segment. Brachygluta fossulata (ca. $1.8 \mathrm{~mm}$ ) and Rybaxis longicornis* (ca. $2.0 \mathrm{~mm}$ ) have less well developed maxillary palps compared to the previously mentioned species. Tyrus mucronatus, a large pselaphine beetle of about $2.3 \mathrm{~mm}$, which is found beneath bark of dead trees, has comparatively small maxillary palps. Finally, Pselaphus heisei (1.8 mm long) has extremely long maxillary palps with a slender and terminally clubbed fourth segment. These species will be referred to by abbreviations in the following text: $B p=$ Bryaxis puncticollis, $B b=$ Bryaxis bulbifer, $B f=$ Brachygluta fossulata, $R l=$ Rybaxis longicornis, $P h=$ Pselaphus heisei, $T m=$ Tyrus mucronatus.

\section{Prey-capture behaviour}

Observations in the laboratory: The beetles were placed in a cuvette or a small labyrinth of plaster of Paris and were presented with different-sized specimens of Heteromurus nitidus. The behavioural responses were filmed at 25 frames/s with conventional digital video cameras (Sony Digital Handycam, DCR-
TRV345E, and Sony Handycam, DCR-HC17E) fitted with close-up lenses (hama Nah (Close-Up) +1 , +2 , and +4). Light was provided by cold-light illuminators (Schott KL105B). Actual data were obtained by single frame analysis of the video recording.

Evaluation of the preferred prey size and the prey-capture success: Beetles that had been starved for two days were placed in small 5 by $5 \mathrm{~cm}$ containers with a base of moist plaster of Paris under natural light conditions, along with defined numbers and size classes of Heteromurus nitidus for two hours [presented prey-size classes: (I) $\leq 0.6 \mathrm{~mm}$, (II) $0.6-0.9 \mathrm{~mm}$, (III) $0.9-1.2$ $\mathrm{mm}$, and (IV) $>1.2 \mathrm{~mm}$ ]. To determine prey-capture success, the absolute number of Collembola caught during these two hours was recorded, and the proportion of the size classes in this catch was used to determine the preferred prey size. In order to avoid any external disturbances, this was conducted as a "blackbox" experiment, i.e., captured Collembola were not replaced. However, since only in a small percentage of these experiments all the Collembola of one size-class were captured, the preference for a specific prey type could be clearly established.

Statistical analysis: If multiple data sets per specimen were available, species-specific grand means were calculated, summarizing the mean values for several individuals. All means and standard deviations refer to these grand means. There was only a single specimen of $T m$ available for behavioural observations (marked as "one individual" in the tables), so that in this case only the means for this specimen together with their standard deviations are given.

All the statistical analyses were performed with SPSS 11.0 (SPSS Inc., Chicago), generally employing univariate analyses of variance (ANOVA) followed by pairwise comparisons employing Student t-tests with a Bonferroni correction.

\section{Morphology}

Sensory organs (i.e., the compound eyes and sensilla on the antennae and maxillary palps) and the mouthparts were examined using scanning and transmission electron microscopy.

For scanning electron microscopy (SEM), the antennae, the maxillary palps, and the mouthparts were removed from the

* According to Besuchet (1989) R. laminata is a synonym of R. longicornis. However, a more recent publication (Hansen et al., 1999) considers them to be two separate species; this is based on male genitalia. In the present study all the specimens were determined using Besuchet (1974, 1989), and therefore treated as R. longicornis. 

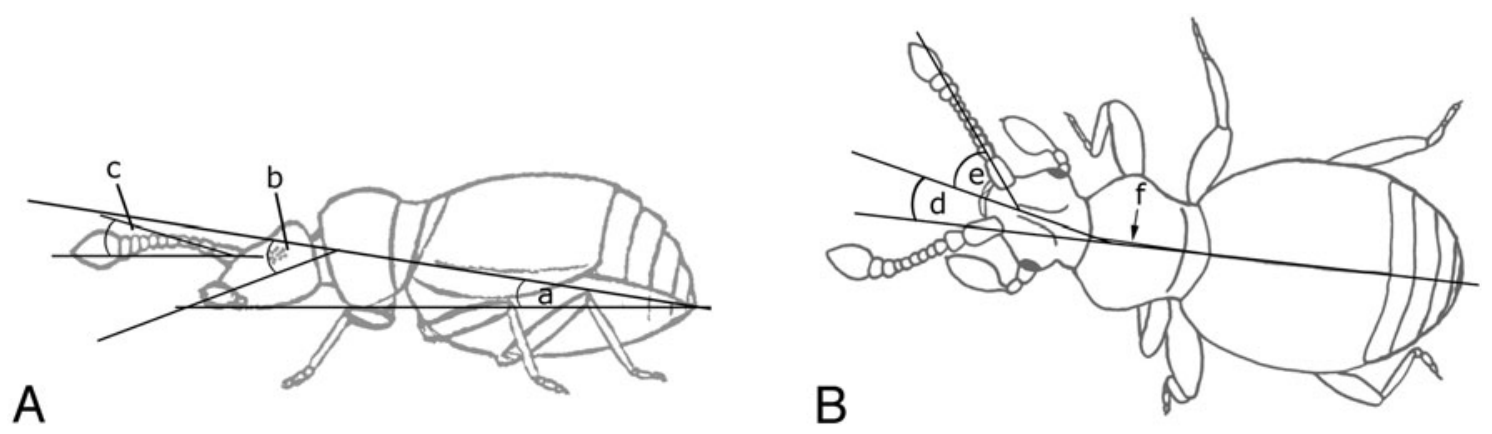

Fig. 1. Body angles referred to in the text and in the tables. (A) Lateral view: (a) body angle [= angle between longitudinal body axis (i.e., the line from the abdominal tip to the elytral humerus) and the ground]; (b) head angle (= angle of the head with respect to the longitudinal body axis); (c) antennal angle [= vertical angle (proximal part) of the antenna with respect to the ground]. (B) Dorsal view: (d) head angle (= angle of the median axis of the head with respect to the median axis of the rest of the body); (e) antennal angle [= horizontal angle of the antenna (proximal part) with respect to the median axis of the head]; (f) pronotum angle [= angle of the median axis of the pronotum with respect to the median axis of the rest of the body - this angle is usually small; here $2^{\circ}$ ( arrow)].

head and attached at their base to SEM stubs by double-sided sticky carbon tape. The objects were then left to dry in a desiccator. Afterwards, the stubs were sputter-coated with gold (Bal-Tec Sputter Coater SCD 050) and examined in a LEO S 402 SEM.

In order to count the ommatidia and measure their diameters, the heads of the beetles were cut in half longitudinally. Each half was then attached to SEM stubs, so that the eye faced upwards. Additionally, the corneae of some individuals were detached, photographed under a light microscope and measured with the help of the software TPSdig (Rohlf, 2004).

For transmission electron microscopy (TEM), individuals were fixed in glutaraldehyde $(2.5 \%$ solution in $0.1 \mathrm{M}$ cacodylate buffer, $\mathrm{pH}$ 7.4) and osmium tetroxide (1\% solution in buffer; 2 h), gradually dehydrated in isopropanol and propylene oxide, and embedded in agar (Agar-100 Resin Kit, Plano). Serial semithin and ultra-thin sections were cut with a diamond knife on a Reichert Ultracut $\mathrm{S}$. The semi-thin sections $(0.5 \mu \mathrm{m})$ were then stained with Richardson solution (Robinson et al., 1985), whereas the ultra-thin sections $(60 \mathrm{~nm})$ were stained with lead citrate (Reynolds) and uranyl acetate (Robinson et al., 1985), and examined using a Philips TEM 208 S. Semi-thin sections were examined using an axioscope (Zeiss) and digitally photographed (Zeiss Axiocam).

Body lengths were measured on dead or stunned individuals by using a binocular and a stage micrometer (Wild, Heerbrugg, Switzerland, No. 310345).

\section{RESULTS}

\section{Behavioural observations}

Prey-capture

The prey-capture behaviour consisted of several steps: (i) searching behaviour, (ii) detection of prey, (iii) approach towards the prey, (iv) prey-capture and finally (v) prey-handling in which the prey is oriented for feeding (species in Table 1). However, this pattern can vary depending on the species, the specific situation and motivation of the individual, with steps omitted or performed in a different way. To facilitate the understanding of the following descriptions pre-defined body angles (Fig. 1) and postures (Figs 2-5) are given.

\section{Searching behaviour (Fig. 2A):}

The labyrinth was searched for prey using slight lateral swinging movements of mainly the head (angle $d$ in Fig. $1 \mathrm{~B}$; only slightly accompanied by the prothorax, angle $\mathrm{f}$ in Fig. 1B) in $B b, B p, B f$ and $R l . P h$ beetles did not move their head or prothorax laterally relative to their abdomen. $\mathrm{Tm}$ beetles moved the whole body axis laterally, plus additional lateral head movements of about $10^{\circ}$ to either side. In $P h$ and $T m$, the movements performed while searching for prey were slower than in the other species (Table 2).

Depending on the species, the antennae are spread at different angles with respect to the median axis (angle e in Fig. 1B). Usually, they are horizontally (angle e in Fig. 1B) and vertically (angle $\mathrm{c}$ in Fig. 1A) swung in a pendulum-like manner ( $P h$ moved them only slightly vertically). On account of the slow and often irregular antennal movement in the two Bryaxis, $P h$ and $T m$ beetles, it was almost impossible to measure the frequencies of movement. This was only possible in $B f$ and $R l$, which move their antennae much faster (up to $11 \mathrm{~Hz}$ in $B f$ and $12.5 \mathrm{~Hz}$ in $R l$, in the vertical direction) in a highly regular manner (Table 2). For the Bryaxis species we can only state that they move their antennae faster than $P h$ and $T m . R l$ and $B f$ also use their antennae for testing irregularities in the surface of the ground.
A

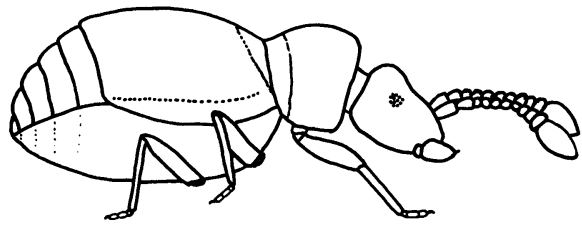

B

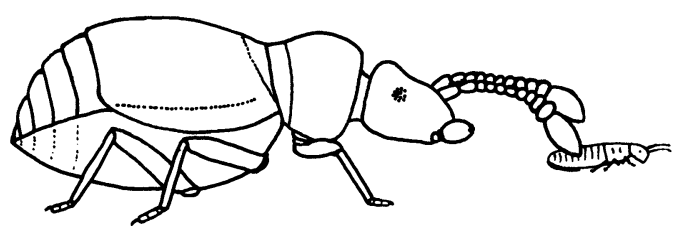

Fig. 2. Predatory behaviour of Bryaxis puncticollis prior to the strike. (A) Search for prey. (B) Detection of prey. For further explanation see text. 
A

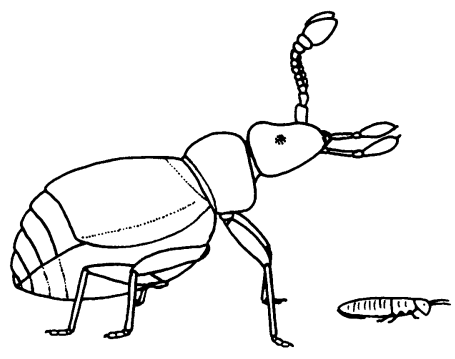

Fig. 3. Prey-capture behaviour in selected Pselaphinae. (A) Upward movement of the body in Bryaxis puncticollis. (B-C) Actual predatory strike [(B) Bryaxis puncticollis and (C) Brachygluta fossulata]. For further explanations see text.

The head is bent downward at different angles relative to the longitudinal body axis in a species-specific manner (angle b in Fig. 1A; Table 2).

The maxillary palps are retracted during searching. They may perform only slight movements and may occasionally be protracted. $B p$ and $T m$ usually perform rapid vibrating movements with the last palpomere during this time. Specimens of $P h$ sporadically stop moving and test the ground slowly with their maxillary palps.

All these movements result in different areas being searched ("width of search path" in Table 2). In contrast to the other species, specimens of $P h$ pursue a slightly meandering path of differing widths.

Prey detection:

The tactile detection of prey takes place with only a slight contact with the antennae (Fig. 2B; regularly observed in $B p, R l$ and $T m$ ) or other parts of the body (observed in $R l$ ). $B b, P h$ and $B f$ beetles change their behaviour immediately prior to contact, so that they seem to detect the prey by olfactory or vibrational cues, the latter possibly transmitted via the substrate or the air.

Approach and preparation of predatory strike:

Approach: $B p, B b, B f$ and $T m$ visibly slow down when approaching their prey. $T m$ even stops for a moment after the first contact with the prey and moves closer to the ground. In contrast $R l$ specimens rush forward with a velocity of up to 8 body lengths per second and, if necessary, pursue moving prey for 0.12 to $0.24 \mathrm{~s}(\mathrm{n}=2)$ at about 5.5 body lengths per second. $R l$ and $T m$ may turn towards the prey when it is located lateral to the body axis of the beetle. The prey is generally located between the antennae, with one or even both antennal tips often pointing directly towards the prey. The antennae are now moved more cautiously. Specimens of $B b, B f$ and $T m$ recurrently seem to touch the prey lightly with the tips of their antennae, which might help them to adjust themselves better with respect to the position of the prey. The maxillary palps are usually retracted in Tm, and slightly or more strongly protracted in the other species.

Preparation for the predatory strike (for all species except Tm whose behaviour will be described in the following section): The beetles perform an upwardly directed movement with their fore bodies prior to the strike (angle a in Fig 1A; Fig. 3A). In the two Bryaxis species and $R l$ the body was moved upwards after having approached the prey. The latter species occasionally made this movement as it rapidly turned towards the prey. Specimens of $B f$ raise their fore body (by about $10^{\circ}$ ) after detecting prey, hold this posture as they approach the prey and complete the movement while making the last step. $P h$ always performs this upward movement while approaching the prey, and thus needs an extra second for preparation, which is about three to five times as long as for the other species. In both Bryaxis species the hind legs are often rapidly extended in order to perform a jump-like forward movement. The different angles of both the body and head are listed in Table 3 . The head is brought into a more prognathous position immediately prior to the strike in all the species. The antennae are usually held diagonally forward and approximately parallel to the ground; only $B p$ (Fig. $3 \mathrm{~A}$ ) and sometimes $R l$ hold their antennae
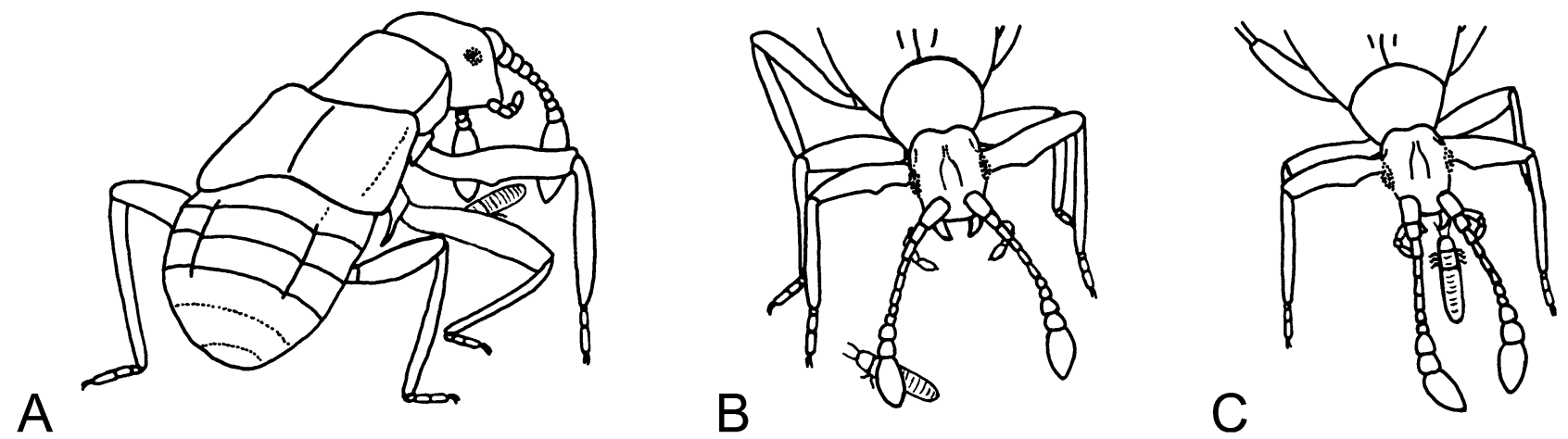

Fig. 4. Preparation for the predatory strike in Tyrus mucronatus. (A) General body posture during this behaviour. (B-C) Driving of the prey toward the mandibles by means of the antennae. For further explanations see text. 

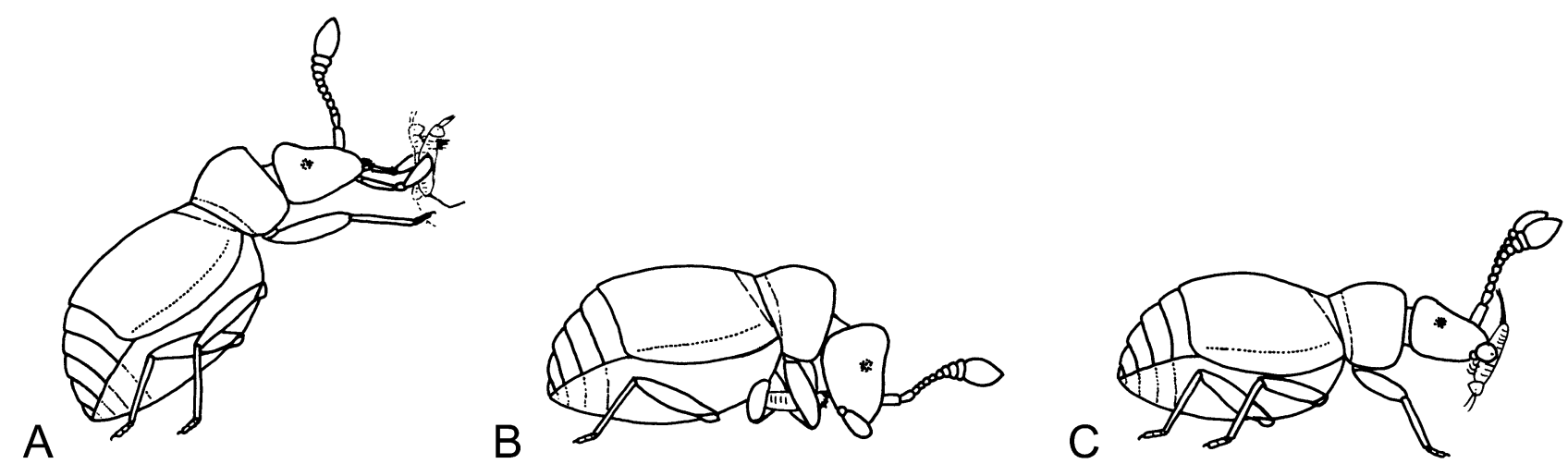

Fig. 5. Characteristic prey-handling behaviour illustrated by that of Bryaxis puncticollis. (A) Handling of the prey in an upright position immediately subsequent to the strike. (B) Holding the prey sandwiched between the tibiae and the femora. (C) Final grasp (note the upward orientation of the furca of the collembolan).

perpendicularly up. As the beetles raise their body, the maxillary palps are either pushed continuously forwards or are, initially, only slowly extended and finally thrust forwards (occurring in $\mathrm{Bb}$ and sometimes in $\mathrm{Bp}$ ). At the end of the upward body movement, the maxillary palps are completely extended. In $R l$ and sometimes $B f$, the palpal extension might in some cases occur only after the following downward movement of the body (predatory strike). Observations on $B f$ reveal that the beetles open their mandibles widely at the end of the upward body movement.

Beetles of Tm perform the upward movement of their fore body (angle a in Fig. 1A) prior to the strike while approaching the prey, as do $P h$ beetles. However, subsequent to this approach, they have a unique way of preparing for prey-capture (Fig. 4). Their prothoracic legs are widely spread laterally, with the tibiae and femora forming an angle of at least $90^{\circ}$ (Fig. 4A). At the same time, both the tibia and tarsus are extended in a straight line towards the ground, which is touched only by the claws or the last tarsomeres (if at all). Lastly, the palps are slowly protruded and the mandibles widely opened. A further approach or angular adjustments relative to the prey might be conducted in this posture, and the beetle leans forward (thereby reducing the body angle, angle a in Fig. 1A; see Table 3). Ideally the prey is now located directly in front of the predator. The antennae are then brought together, each forming an angle of about $30^{\circ}$ with respect to the median line (angle e in Fig. 1B), and are held nearly parallel to the ground. They are moved continuously downwards and inwards, and the prey is frequently touched by the tips of the antennae. This enables

TABLE 2. Searching behaviour of Pselaphinae. Searching velocities, the head angles (mean angles of deflection of the head horizontally and vertically, Fig. 1), the positions and movement of the antennae (average maximum and minimum angles with respect to the median axis during movement, and frequency), and the resulting widths of the search path. The numbers represent grand means [ \pm standard deviations (SD)] and, in some cases, statistical ranges (labelled "range"). In Tyrus mucronatus (one individual), the statistics refer to repeated observations on one individual. "n" refers to the number of individuals, except in Tyrus mucronatus, where it is the number of observations on one individual.

\begin{tabular}{|c|c|c|c|c|c|c|}
\hline & $\begin{array}{c}\text { Bryaxis } \\
\text { puncticollis }\end{array}$ & Bryaxis bulbifer & $\begin{array}{l}\text { Brachygluta } \\
\text { fossulata }\end{array}$ & $\begin{array}{l}\text { Rybaxis } \\
\text { longicornis }\end{array}$ & Pselaphus heisei & $\begin{array}{l}\text { Tyrus mucronatus } \\
\text { (one individual) }\end{array}$ \\
\hline $\begin{array}{l}\text { Searching velocity } \\
\text { (body lengths/s) }\end{array}$ & $\begin{array}{c}1.49 \pm 0.7(\mathrm{n}=7 \\
\text { range: } 0.5-2.5)\end{array}$ & $\begin{array}{c}1.57 \pm 0.6(\mathrm{n}=7 \\
\text { range: } 1.0-3.6)\end{array}$ & $\begin{array}{c}1.96 \pm 0.6(\mathrm{n}=7 \\
\text { range: } 1.2-3.7)\end{array}$ & $\begin{array}{l}1.73 \pm 0.4(\mathrm{n}=6 \\
\text { range: } 1.0-3.6)\end{array}$ & $\begin{array}{l}0.93 \pm 0.5(\mathrm{n}=4 \\
\text { range: } 0.4-1.9)\end{array}$ & $\begin{array}{c}0.58 \pm 0.3(\mathrm{n}=15 \\
\text { range: } 0.3-1.1)\end{array}$ \\
\hline $\begin{array}{l}\text { Horizontal head } \\
\text { angle }\left(^{\circ}\right) \text { (angle d } \\
\text { in Fig. 1B) }\end{array}$ & $8.3 \pm 3(n=3)$ & $11 \pm 4(\mathrm{n}=3)$ & $11.3 \pm 2(n=3)$ & $10.8 \pm 3(n=3)$ & $0 \pm 0(\mathrm{n}=4)$ & $9.3 \pm 6(n=8)$ \\
\hline $\begin{array}{l}\text { Vertical head angle } \\
\left({ }^{\circ}\right) \text { (angle b in Fig. } \\
\text { 1A) }\end{array}$ & $46.6 \pm 2(n=7)$ & $42.5 \pm 2(n=7)$ & $49.6 \pm 5(n=6)$ & $55.8 \pm 3(n=6)$ & $38.8 \pm 8(n=4)$ & $51.8 \pm 5(\mathrm{n}=11)$ \\
\hline $\begin{array}{l}\text { Horizontal antennal } \\
\text { angle (range of the } \\
\text { movement) }\left({ }^{\circ}\right) \\
\text { (angle e in Fig. 1B) }\end{array}$ & $\begin{array}{c}35.0 \pm 13 \text { to } \\
61.6 \pm 14(\mathrm{n}=3)\end{array}$ & $\begin{array}{c}36.3 \pm 8 \text { to } \\
53.3 \pm 6(n=3)\end{array}$ & $\begin{array}{c}21.6 \pm 8 \text { to } \\
64.2 \pm 12(n=3)\end{array}$ & $\begin{array}{c}30.9 \pm 4 \text { to } \\
59.3 \pm 1(\mathrm{n}=3)\end{array}$ & 35 to $60(n=1)$ & $\begin{array}{c}38.5 \pm 9 \text { to } \\
57 \pm 13(\mathrm{n}=10)\end{array}$ \\
\hline $\begin{array}{l}\text { Frequency of } \\
\text { antennal movement } \\
(\mathrm{Hz})\end{array}$ & (irregular) & (irregular) & $\begin{array}{c}6.35 \pm 2.0(\mathrm{n}=7 \\
\text { maximum } 11.1)\end{array}$ & $\begin{array}{c}6.75 \pm 1.5(\mathrm{n}=6 \\
\text { maximum } 12.5)\end{array}$ & (irregular) & (irregular) \\
\hline $\begin{array}{l}\text { Width of search } \\
\text { path (individual } \\
\text { head widths) }\end{array}$ & $\begin{array}{c}4.11 \pm 0.5(\mathrm{n}=3) \\
\text { maximum } 4.4\end{array}$ & $\begin{array}{c}4.72 \pm 0.4(\mathrm{n}=3) \\
\text { maximum } 5.0\end{array}$ & $\begin{array}{c}5.77 \pm 0.3(\mathrm{n}=3) \\
\text { maximum } 6.2\end{array}$ & $\begin{array}{c}5.64 \pm 0.3(\mathrm{n}=3) \\
\text { maximum } 6.7\end{array}$ & $<5(\mathrm{n}=1)$ & $\begin{array}{c}5.41 \pm 0.6(\mathrm{n}=7) \\
\text { maximum } 6.4\end{array}$ \\
\hline
\end{tabular}


TABle 3. Prey-capture behaviour of Pselaphinae. Body postures at the end of the upward movement prior to the strike (body angle a and head angle $\mathrm{b}$ in Fig. 1A) and time needed for the subsequent downward movement during the strike (Figs 3 B-C). The numbers usually represent grand means $[ \pm$ standard deviations $(\mathrm{SD})]$ and statistical ranges (time only, in brackets). For Tyrus mucronatus (one individual), the statistics presented refer to repeated observations on only one individual (the maximum value is the maximum angle, as due to subsequent additional forward corrections of its body posture the previous angle is diminished shortly before the strike; for further information see text). "n" refers to the number of individuals, except for Tyrus mucronatus, where it is the number of observations on one individual.

\begin{tabular}{|c|c|c|c|c|c|c|}
\hline & $\begin{array}{c}\text { Bryaxis } \\
\text { puncticollis }\end{array}$ & $\begin{array}{l}\text { Bryaxis } \\
\text { bulbifer }\end{array}$ & $\begin{array}{l}\text { Brachygluta } \\
\text { fossulata }\end{array}$ & $\begin{array}{l}\text { Rybaxis } \\
\text { longicornis }\end{array}$ & $\begin{array}{l}\text { Pselaphus } \\
\text { heisei }\end{array}$ & $\begin{array}{l}\text { Tyrus mucronatus } \\
\text { (one individual) }\end{array}$ \\
\hline $\begin{array}{l}\text { Body angle }\left({ }^{\circ}\right) \\
\text { (angle a in Fig. } \\
\text { 1A) }\end{array}$ & $26.0(\mathrm{n}=2)$ & $21.6 \pm 7(n=3)$ & $19.3 \pm 10(n=6)$ & $26.9 \pm 1(\mathrm{n}=3)$ & $17.5 \pm 3(n=3)$ & $\begin{array}{c}\text { Maximum: } \\
30.0 \pm 6(\mathrm{n}=5) \\
\text { shortly before strike } \\
10.7 \pm 4(\mathrm{n}=7)\end{array}$ \\
\hline $\begin{array}{l}\text { Head angle }\left(^{\circ}\right) \\
\text { (angle b in Fig. } \\
\text { 1A) }\end{array}$ & $20.8 \pm 4(n=3)$ & $24.2 \pm 19(\mathrm{n}=3)$ & $35.0 \pm 14(\mathrm{n}=6)$ & $36.2 \pm 8(n=3)$ & $23.0 \pm 12(\mathrm{n}=3)$ & $32.9 \pm 11(n=7)$ \\
\hline $\begin{array}{l}\text { Time for final } \\
\text { strike (s) (mean } \\
\pm \text { SD; range) } \\
\end{array}$ & $\begin{array}{c}0.047 \pm 0.01(\mathrm{n}=3) \\
\quad(<0.04-0.08)\end{array}$ & $\begin{array}{c}0.070 \pm 0.03(\mathrm{n}=4) \\
\quad(<0.04-0.12)\end{array}$ & $\begin{array}{c}0.110 \pm 0.04(\mathrm{n}=4) \\
\quad(0.08-0.16)\end{array}$ & $\begin{array}{c}0.108 \pm 0.07(\mathrm{n}=4) \\
\quad(0.04-0.24)\end{array}$ & $\begin{array}{c}0.633 \pm 0.24(\mathrm{n}=3) \\
\quad(0.16-0.80)\end{array}$ & $\begin{array}{c}0.055 \pm 0.02(\mathrm{n}=6) \\
\quad(<0.04-0.08)\end{array}$ \\
\hline
\end{tabular}

the beetle to locate the prey precisely and causes the prey to move gradually towards its mouthparts, often exactly below the widely opened mandibles (Figs 4B-C). If the prey has, however, moved on and is no longer within the reach of the beetle, the antennal inward and downward movement is continued, until an angle of about $13^{\circ}$ to the median line (angle e in Fig. 1B) and a vertical angle of $-53^{\circ}$ with respect to a horizontal line parallel to the ground (angle $\mathrm{c}$ in Fig. 1A) is reached. Otherwise it stops once the prey is immediately below the widely open mandibles. The first complete antennal inward movement without contacting or driving the prey below the mandibles takes about $2.2 \pm 0.2 \mathrm{~s}(\mathrm{n}=3$, measured on one individual). The movement can then be repeated several times (often over only a smaller part of the area), and the time needed for these repetitions is very variable. If the prey is already located below the mouthparts, the antennae are not moved inwards.

In conclusion, the main difference between $T m$ and the other species in the preparation for the strike is that $\mathrm{Tm}$ beetles actively drive the prey towards their mandibles, whereas the other beetles move towards the prey.

Predatory strike:

The predatory strike consists of a rapid downward movement of the fore body (angle a in Fig. 1A) in most of the species, and the prey is captured either with the mandibles, by means of the apparently sticky maxillary palps, or, in the case of $T m$, by the fore and middle legs. In addition to the downward movement, $B p, B f$ and $P h$ beetles bend their heads downwards with respect to the pronotum (angle $b$ in Fig. 1A). Table 3 lists the different periods of time recorded for different species for this downward movement. Specimens of all the species, with the exception of $T m$, stretched out their maxillary palps and placed them upon the dorsal surface of the prey (Figs 3B-C). In the two Bryaxis species, this seems to be sufficient to restrain the prey, although $B p$ beetles also sometimes additionally use their mandibles. $P h$ has an additional second phase of downward movement, during which they lower their opened mandibles towards the prey, which is

TABLE 4. Prey-handling behaviour of Pselaphinae. Average durations of prey-handling subsequent to the strike [in upright posture (Fig. 5A) and while holding the prey sandwiched with the forelegs (Fig. 5B)], the corresponding body angles (in the upright position), and the angles of the head while holding the prey (large angles achieved by simultaneously bending the pronotum downwards). The numbers represent grand means [ \pm standard deviations (SD)]. In Tyrus mucronatus (one individual), the statistics refer to repeated observations on one individual. " $n$ " refers to the number of individuals, except in Tyrus mucronatus, where it is the number of observations on one individual. For further explanations see text.

\begin{tabular}{|c|c|c|c|c|c|c|}
\hline & $\begin{array}{c}\text { Bryaxis } \\
\text { puncticollis }\end{array}$ & $\begin{array}{l}\text { Bryaxis } \\
\text { bulbifer }\end{array}$ & $\begin{array}{l}\text { Brachygluta } \\
\text { fossulata }\end{array}$ & $\begin{array}{c}\text { Rybaxis } \\
\text { longicornis }\end{array}$ & $\begin{array}{c}\text { Pselaphus } \\
\text { heisei }\end{array}$ & $\begin{array}{c}\text { Tyrus mucronatus } \\
\text { (one individual) }\end{array}$ \\
\hline $\begin{array}{l}\text { Duration of upright posture } \\
\text { (s) }\end{array}$ & $1.44(\mathrm{n}=1)$ & $\begin{array}{l}1.26 \pm 0.4 \\
(\mathrm{n}=3)\end{array}$ & $\begin{array}{l}1.97 \pm 1.3 \\
(\mathrm{n}=5)\end{array}$ & $\begin{array}{c}1.0(\mathrm{n}=1 \\
\text { often skipped })\end{array}$ & $\begin{array}{c}1.64 \\
(\mathrm{n}=1)\end{array}$ & (did not occur) \\
\hline $\begin{array}{l}\text { Body angle }\left({ }^{\circ}\right) \text { (upright; } \\
\text { angle a in Fig. 1A) }\end{array}$ & $\begin{array}{l}63.3 \pm 8 \\
(\mathrm{n}=3)\end{array}$ & $\begin{array}{c}50.6 \pm 12 \\
(\mathrm{n}=4)\end{array}$ & $\begin{array}{c}54.4 \pm 12 \\
(\mathrm{n}=4)\end{array}$ & $\begin{array}{c}50 \\
(\mathrm{n}=1)\end{array}$ & $\begin{array}{c}62.5 \\
(\mathrm{n}=2)\end{array}$ & (did not occur) \\
\hline $\begin{array}{l}\text { Duration for which the prey } \\
\text { is held sandwiched with the } \\
\text { forelegs (s) }\end{array}$ & $\begin{array}{c}4.08 \\
(n=1)\end{array}$ & $\begin{array}{l}4.32 \pm 4.2 \\
(\mathrm{n}=4)\end{array}$ & $\begin{array}{l}1.66 \pm 1.3 \\
(\mathrm{n}=5)\end{array}$ & $\begin{array}{l}1.53 \pm 0.6(\mathrm{n}=3, \\
\text { prey only turned, } \\
\text { not sandwiched })\end{array}$ & $\begin{array}{l}1.04 \\
(\mathrm{n}=1)\end{array}$ & $\begin{array}{l}6.22 \pm 3.9 \\
(\mathrm{n}=5)\end{array}$ \\
\hline $\begin{array}{l}\text { Head angle }\left(^{\circ}\right) \text { (while prey } \\
\text { is held sandwiched with the } \\
\text { forelegs; angle } b \text { in Fig. } 1 \mathrm{~A} \text { ) }\end{array}$ & $\begin{array}{c}100 \\
(\mathrm{n}=1)\end{array}$ & $\begin{aligned} & 94 \pm 12 \\
&(\mathrm{n}=3)\end{aligned}$ & $\begin{array}{l}108 \pm 18 \\
(\mathrm{n}=5)\end{array}$ & (see above) & $\begin{array}{c}100 \\
(n=1)\end{array}$ & $\begin{array}{l}115 \pm 9 \\
(\mathrm{n}=3)\end{array}$ \\
\hline
\end{tabular}



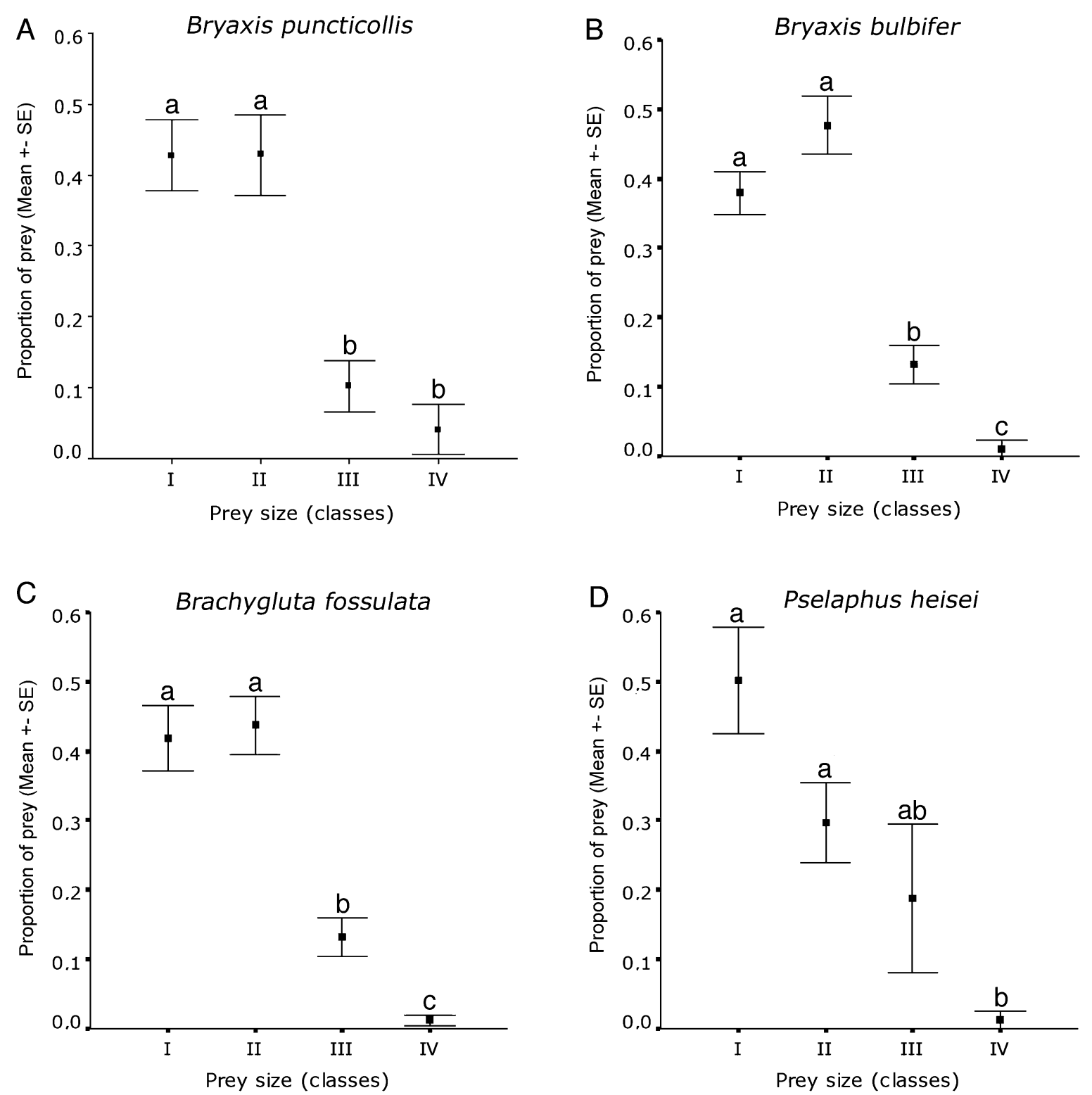

Fig. 6. Preferred size of the collembolan prey (Heteromurus nitidus). Proportion of each of four prey sizes in the total amount of prey caught (points $=$ grand means). The error bars mark the standard error $(\mathrm{SE})$. (Size classes: $\mathrm{I}=\leq 0.6 \mathrm{~mm}, \mathrm{II}=0.6-0.9 \mathrm{~mm}$, III $=$ 0.9-1.2 mm, IV =>1.2 mm. Sample sizes: Bryaxis puncticollis $\mathrm{n}=29$, Bryaxis bulbifer $\mathrm{n}=8$, Brachygluta fossulata $\mathrm{n}=18$, Pselaphus heisei $\mathrm{n}=9$ ). Different small letters above the error bars indicate statistically significant interspecific differences (Student $\mathrm{t}$-test with Bonferroni correction; $\mathrm{p}<0.05$ ).

finally seized and pressed on the ground. The prey sometimes gets stuck to their maxillary palps and can, in this way, be lifted towards the mandibles or escape is prevented to a certain degree. $R l$ and $B f$ beetles also place their maxillary palps on the dorsal surface of the prey (Fig. 3C), even though there is no clear indication of a sticky surface of the palps. These beetles push the prey down and then seize it with their mandibles. In contrast to $P h$, beetles of these species perform the whole downward movement in one quick action. The maxillary palps of $R l$ are sometimes placed on either side of the prey, possibly to hold it in place.

Tm again differs in its method of capturing prey. At the beginning of the downward movement of the fore body, the maxillary palps may be widely extended for a short time. Thereafter, the pro- and mesothoracic tibiae and tarsi are pulled rapidly inwards, and the beetle crouches down. Similar to the predatory strike of a mantis, the prey is seized between the tibia and the trochantero-femoral spines and ridges of the fore legs and, to a lesser extent, the middle legs. Lastly, the head is bent downwards and the prey may also be seized by the mandibles.

In the case of an unsuccessful predatory strike, the two Bryaxis species, $B f$ and $R l$ often search the ground near their heads using their maxillary palps. They may even bite the plaster with their mandibles. $P h$ beetles show a special searching pattern, which resembles the behaviour of $T m$ when preparing to strike. If after the downward movement the maxillary palps or the mandibles do not contact the prey, both the maxillary palps and the 


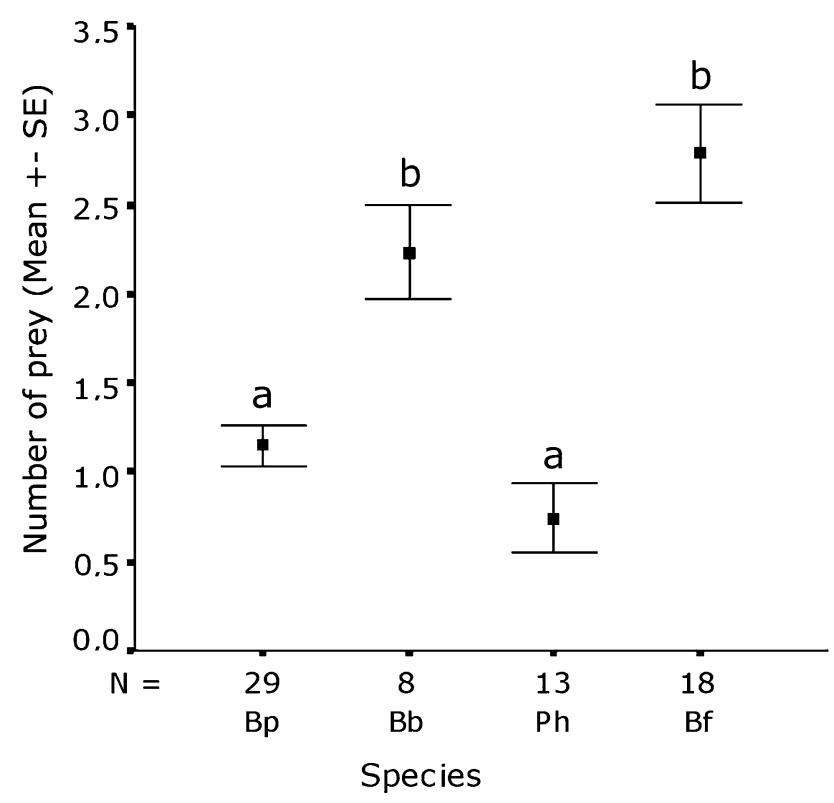

Fig. 7. Mean number of prey captured in two hours. The points represent grand means of caught collembolans (total numbers), ignoring prey size. The error bars mark the standard error (SE). Significantly different groups are marked by different small letters (Student t-test with Bonferroni adjustment, $\mathrm{p}$ $=0.01$ ). Abbreviations: $\mathrm{N}=$ sample sizes, $\mathrm{Bp}=$ Bryaxis puncticollis, $\mathrm{Bb}=$ Bryaxis bulbifer, $\mathrm{Ph}=$ Pselaphus heisei, $\mathrm{Bf}=$ Brachygluta fossulata.

antennal tips are swept over the ground, distally to proximally. If this is not successful, it may be repeated several times. Each cycle takes about $1.5 \mathrm{~s}$. This behaviour may locate nearby prey, often causing it to move towards the predator. Finally, the maxillary palps are placed on the dorsal surface of the prey, so that the second phase of the downward movement (as described above) can take place, ending in prey capture.

Prey handling and final seizure:

Immediately subsequent to the strike individuals of all the species except $\mathrm{Tm}$ raise their fore bodies in order to lift the prey off the ground (Fig. 5A). While doing this, they manipulate the prey with their fore legs (tibiae and tarsi), while the middle and hind legs ensure a firm stance. The different periods of time spent in this position are given in Table 4 . The struggling prey may generate abnormally steep angles of the beetle's body with respect to the ground (generally, a maximum angle of $70^{\circ}$ is observed, although in $\mathrm{Bp}$ it can be $105^{\circ}$; see Table 4 for means). Sometimes the beetle is even knocked over. The prey is held in the mandibles $(B f, R l$, and $P h)$ or stuck to at least one maxillary palpus in Bryaxis spp. (sometimes also in $P h$ ). Even when the prey was seized using the mandibles, the maxillary palps of $B f$ and $R l$ sometimes remain in contact with the prey. The antennae are extended anteriorly in $B b$ and $B f$, and seem to form a mechanical barrier preventing the escape of the prey.

Most species drew the prey towards their ventral side and sandwiched it between both the tibiae and the femora of the fore and often the middle legs (depending on prey size), at the same time lowering the anterior part of their body (Fig. 5B). They now take a posture similar to that adopted by $\mathrm{Tm}$ beetles after their strike. All species, including $T m$, continue in approximately the same manner. Further adjustments of the prey are often necessary. To attain this the head is usually bent by about $100^{\circ}$ (Table 4) relative to the longitudinal body axis. Finally a permanent grasp with the mandibles is achieved. The grasp of the legs is then relaxed and the prey lifted up in the mandibles (see Table 4 for the specific durations of the period the prey is held with the legs).

$R l$ beetles often omit the first part of the prey-handling behaviour sequence (i.e., the upright posture) and even reduce the second part (prey held with the legs), just turning but not grasping the prey with the forelegs. The mandibular grasp is supported by pressing the prey to the ground with the mandibles. In $B p$ passive prey might only be manipulated using the maxillary palps and the fore legs without sandwiching it. In this case the maxillary palps are only moved away after achieving a firm hold with the mandibles.

Finally, all the beetles usually hold the collembolan so that its extended furca points upwards (Fig. 5C), irrespective of the initial orientation of the prey. This prevents the prey from harming the predator and makes it more difficult for the prey to escape. Some beetles do not show a specific prey-handling behaviour if the prey is exceptionally passive $(B p)$ or small ( $R l$, see above), and as a result the furca of the collembolan does not necessarily point upwards.

TABLE 5. Number of ommatidia per eye and the mean surface area of the cornea $\left[\mathrm{mm}^{2}\right]$ of Pselaphinae. Means \pm standard deviations (sex-specific differences in the number of ommatidia were only observed in Bryaxis puncticollis). " $\mathrm{n}$ " refers to the number of individuals in the column "number of ommatidia per eye" and to the number of ommatidia measured in the column "surface area of the cornea".

\begin{tabular}{lcc}
\hline Species & Number of ommatidia per eye & Surface area of the cornea $\left[\mathrm{mm}^{2}\right]$ \\
\hline Bryaxis puncticollis (male) & $23 \pm 2(\mathrm{n}=20)$ & $0.0074 \pm 0.001(\mathrm{n}=20)$ \\
Bryaxis puncticollis (female) & $14 \pm 1(\mathrm{n}=20)$ & $0.0053 \pm 0.002(\mathrm{n}=20)$ \\
Bryaxis bulbifer & $20 \pm 3(\mathrm{n}=8)$ & $0.0089 \pm 0.001(\mathrm{n}=20)$ \\
Brachygluta fossulata & $35 \pm 2(\mathrm{n}=11)$ & $0.0121 \pm 0.002(\mathrm{n}=20)$ \\
Rybaxis longicornis & $30 \pm 2(\mathrm{n}=11)$ & $0.0331 \pm 0.006(\mathrm{n}=20)$ \\
Pselaphus heisei & $24 \pm 1(\mathrm{n}=14)$ & $0.0184 \pm 0.005(\mathrm{n}=20)$ \\
Tyrus mucronatus & $42(\mathrm{n}=1)$ & not measured \\
\hline
\end{tabular}




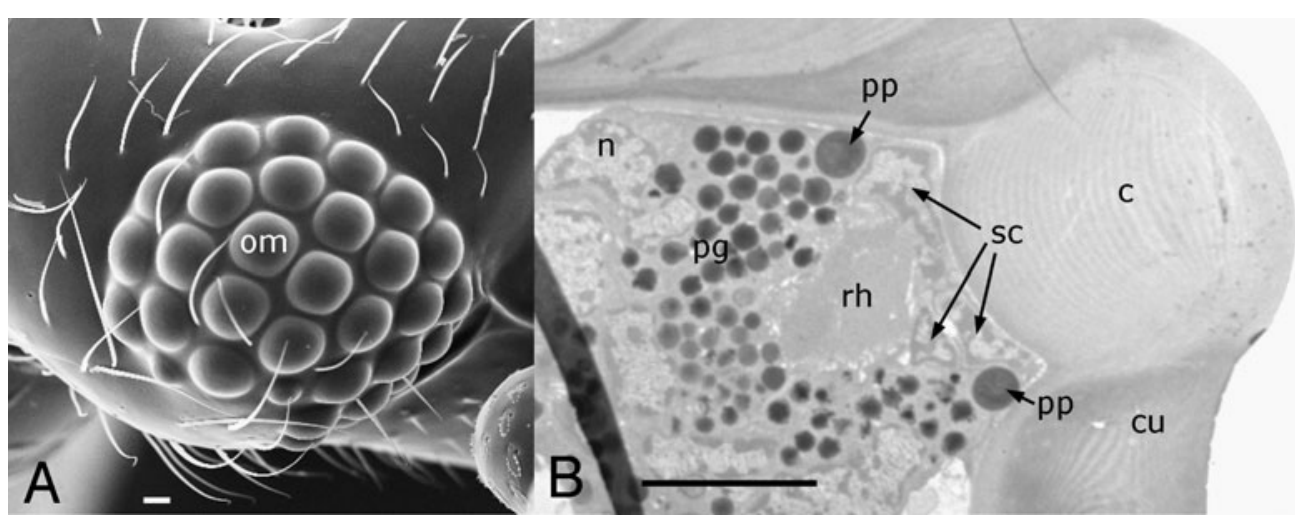

Fig. 8. Eyes of Pselaphinae. (A) SEM-micrograph of a lateral view of the compound eye of Rybaxis longicornis. The large and convex ommatidia are clearly visible. Bar $=10 \mu \mathrm{m}$. (B) TEM-micrograph of a single ommatidium of Bryaxis puncticollis (axial section). $\mathrm{Bar}=5 \mu \mathrm{m}$. Abbreviations: $\mathrm{c}=$ cornea, $\mathrm{cu}=$ cuticle, $\mathrm{n}=$ nucleus, $\mathrm{om}=$ ommatidium, $\mathrm{pg}=$ pigment granules, $\mathrm{pp}=\mathrm{primary}$ pigments, $\mathrm{rh}=$ rhabdome, $\mathrm{sc}=$ Semper cells.

In all species the maxillary palps are not involved in feeding and are usually held laterally. Even during feeding the beetles might react to other prey animals (observed in $B p$ and $R l$ ). In most cases the antennae, the maxillary palps, and at least the tarsi of the fore legs are cleaned after feeding. This might also include selfgrooming of other parts of the body.

\section{Preferred prey size and prey-capture success}

All species tested (both Bryaxis, $B f$, and $P h$; see Table 1) prefer the smallest and the second smallest $(<0.9 \mathrm{~mm})$ of the prey offered (Fig. 6).

$B b$ and $B f$ were more successful predators than $B p$ and $P h$ (Fig. 7) with respect to the prey species used. This is again not related to the size of the predator.

\section{Morphology}

Mainly $B p, B b, B f, R l$, and $P h$ were used for the morphological studies (Table 1). Tm and Bythinus burrelli were only partially studied (eyes resp. antennae).

\section{Sensory organs}

As described earlier, pselaphine beetles seem to rely on tactile and olfactory cues to find prey and orient themselves. The following section presents information on the various sensory organs (eyes, antennae, maxillary palps) likely to be important for prey-finding.

Eyes:

The compound eyes are composed of only a few ommatidia, which are relatively large in size, convex and distinguishable at low magnifications $(10 \times)$ (Fig. 8A). The range in numbers of ommatidia is small and speciesspecific. The males and females of $B p$ have significantly different numbers of ommatidia, with 23 in males and 14 in females (Table 5). Such intraspecific differences were not found in any of the other species in this study.

Pselaphines have apposition ommatidia of the acone type (Meyer-Rochow, 1999; Fig. 8B), i.e., without a distinct crystal cone. The corneal lenses (c in Fig. 8B) consist of a multitude of separate layers, which are separated from each other by unmodified cuticle (cu in Fig. 8B).
A

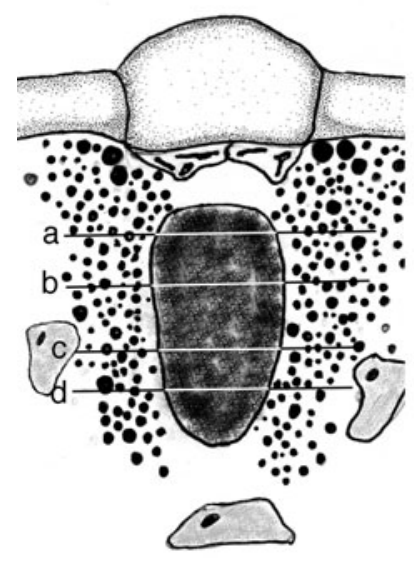

B

a

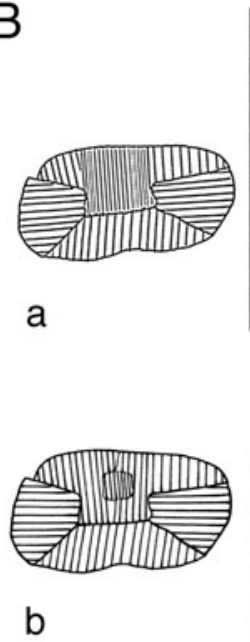

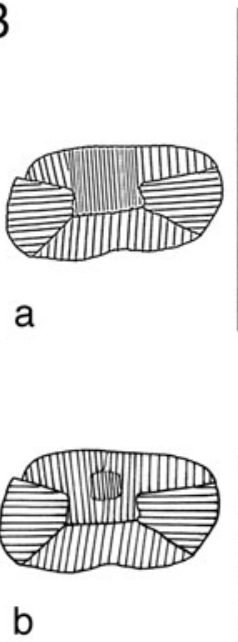

b
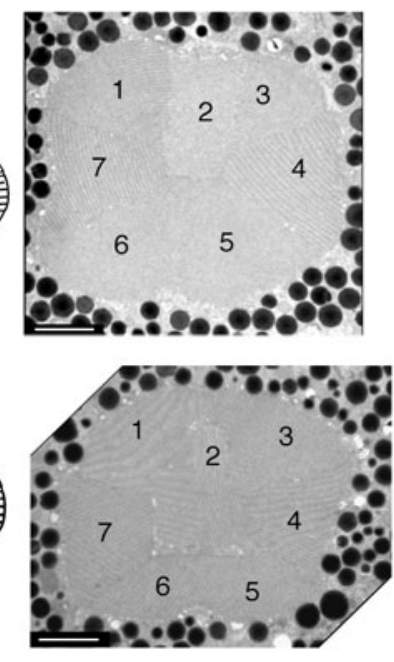

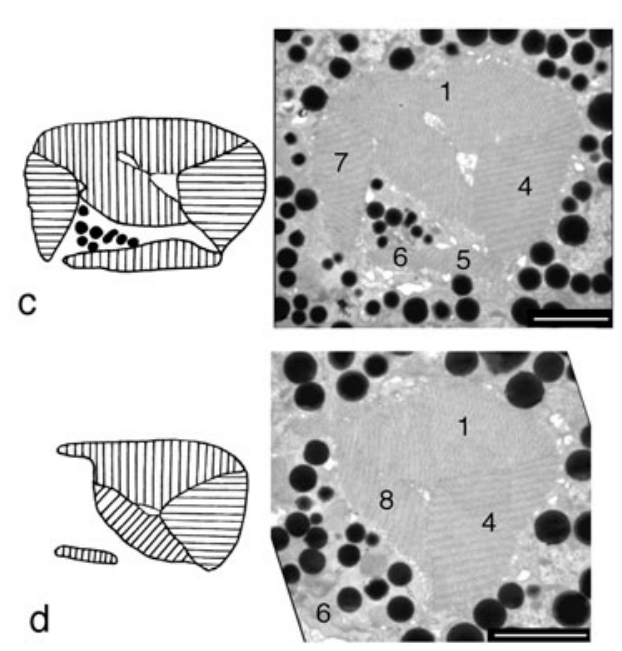

Fig. 9. (A) Representation of a pselaphine ommatidium, with the different cross sectional planes indicated as a-d. (B) The four drawings and TEM-micrographs are of cross sections through the rhabdome of Pselaphus heisei at the levels indicated in (A). The numbers $(1-8)$ in the photographs refer to separate rhabdomeres. Bar $=2 \mu \mathrm{m}$. 

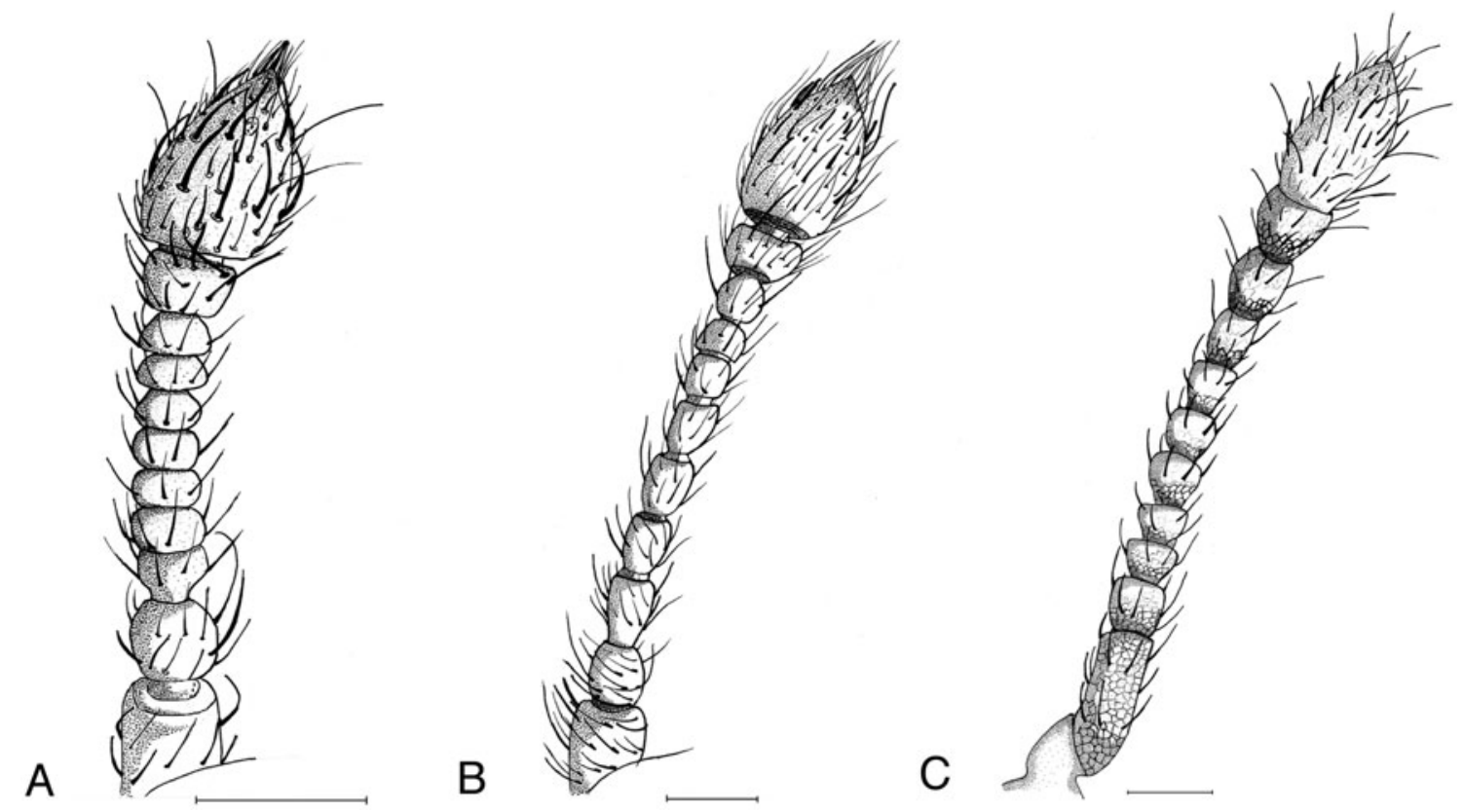

Fig. 10. Schematic drawing of the antennae of (A) Bryaxis puncticollis, (B) Brachygluta fossulata and (C) Pselaphus heisei. Bars $=100 \mu \mathrm{m}$.

Pigment granules occur beneath the cornea, appearing as black spherical components that enclose the rhabdome (pg in Fig. 8B). Particularly large granules in the apical regions of the ommatidia (primary pigments, pp in Fig. $8 \mathrm{~B}$ ) occur in the Bryaxis species. Two to three nuclei of Semper cells (sc in Fig. 8A-B) occur immediately below the cornea.

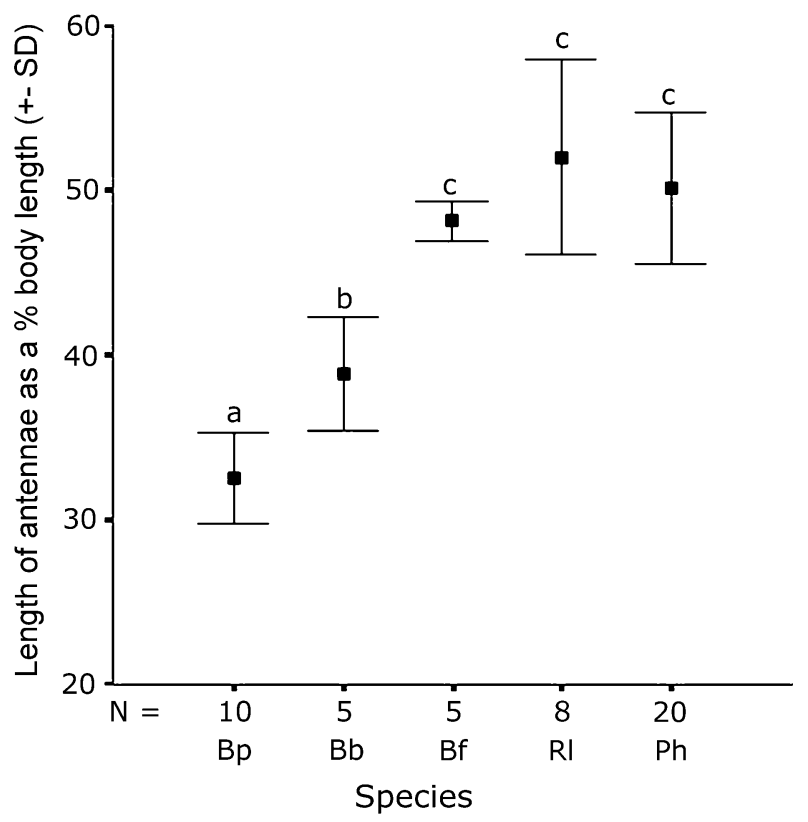

Fig. 11. Average length of the antennae as a percentage of the body length [means \pm standard deviation (SD)]. Abbreviations: $\mathrm{N}=$ sample sizes, $\mathrm{Bp}=$ Bryaxis puncticollis, $\mathrm{Bb}=$ Bryaxis bul bifer, $\mathrm{Bf}=$ Brachygluta fossulata, $\mathrm{R} 1=$ Rybaxis longicornis, $\mathrm{Ph}$ = Pselaphus heisei. Different small letters above the error bars indicate statistically significant interspecific differences (Student t-test with Bonferroni adjustment; $\mathrm{p}<0.05$ ).
The rhabdome is closed (i.e., the rhabdomeres are fused), and consists of eight rhabdomeres (Fig. 9). A wedge-shaped rhabdomere (labelled 2 in Fig. 9Ba) is present in the distal part of the rhabdome, which extends in a proximal direction and is surrounded by two other rhabdomeres (labelled 1 and 3 in Fig. 9Bb). The basal part contains only three rhabdomeres, two of which occur along the entire length of the rhabdome (labelled 1 and 4 in Fig. 9Bd). The third rhabdomere (labelled 8 in Fig. 9Bd) does not extend far distally.
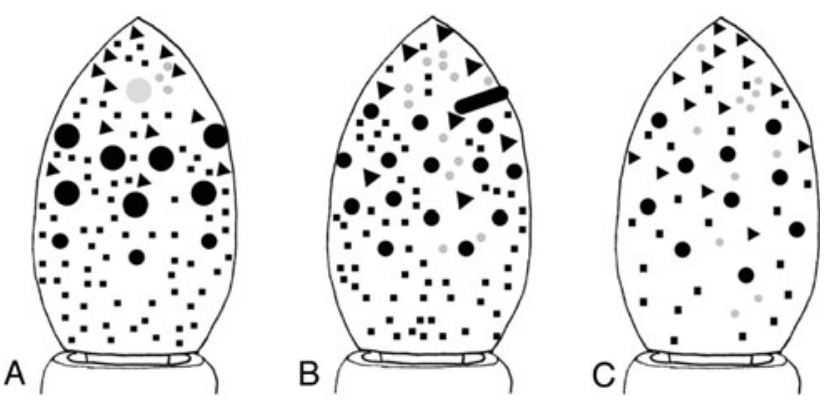

Fig. 12. Representation of the sensilla complement on the 11th antennomere of (A) Bryaxis puncticollis, (B) Brachygluta fossulata and (C) Pselaphus heisei based on the structural analysis. Different symbols represent the different types of sensilla; their sizes and numbers reflect the relative sizes and the proportional quantities of sensilla. Large black circles $=$ large sw-wp sensilla; small black circles = small sw-wp sensilla; small grey circles $=\mathrm{dw}$-wp sensilla; triangles $=$ long projecting sensilla; large grey circle = trichobothrium-like sensillum; small black square = probably simple mechanoreceptive sensilla; long black bar $=$ crescent-shaped aggregation of sw-wp sensilla. Abbreviations: $d w-w p=$ double-walled wall pore sensillum, $\mathrm{sw}-\mathrm{wp}=$ single-walled wall pore sensillum. 


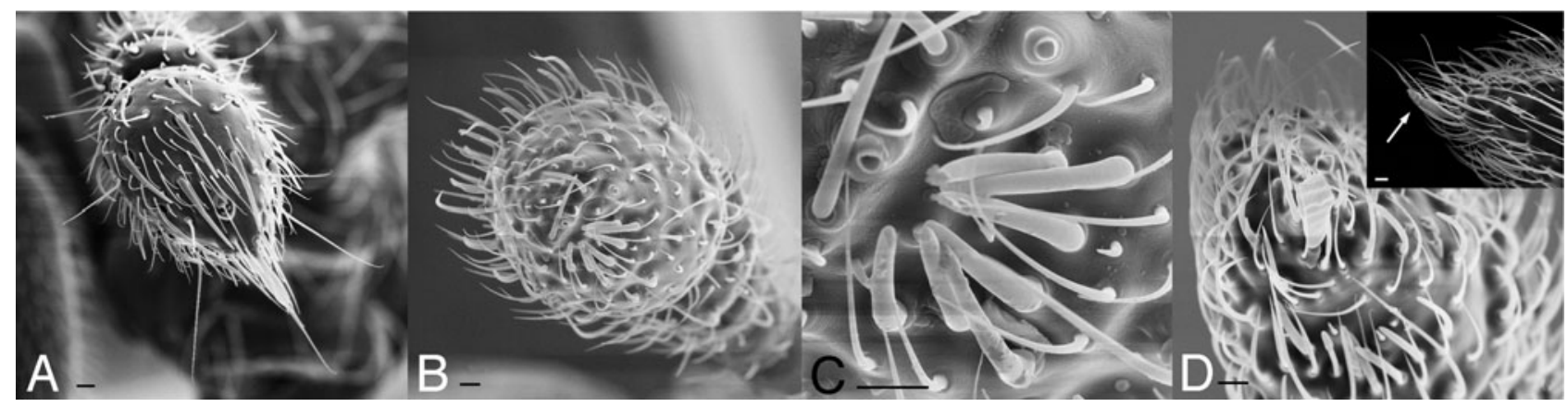

Fig. 13. Overview of the peculiar structures found on the terminal antennomeres. (A) Array of sensilla in Bryaxis bulbifer. (B-C) Crescent-shaped aggregation of 7 single-walled wall pore (sw-wp) sensilla in Brachygluta fossulata. (D) Flat seta at the tip of the 11th antennomere in Rybaxis longicornis (inset for orientation); the less conspicuous crescent-shaped aggregation of $7 \mathrm{sw}-\mathrm{wp}$ sensilla is visible in the lower part of the picture. Bars $=10 \mu \mathrm{m}$.

\section{Antennae:}

The pselaphine antennae, which can be described as clubbed in the species studied, are composed of 11 antennomeres: a scape, a pedicel and a flagellum of 9 segments (Fig. 10). The club is composed of the terminal three antennomeres (9-11), and is especially conspicuous in Bryaxis species. The relative length of the antennae varies with body length and is significantly larger in the larger species, i.e., $B f, R l$ and $P h$. The antennal length can reach $50 \%$ of the body length or more (Fig. 11) in these species. The absolute length of the antennae ranges from $0.44 \mathrm{~mm}$ $(B p ; \mathrm{SD}=0.034, \mathrm{n}=10)$ to $0.96 \mathrm{~mm}(R l ; \mathrm{SD}=0.068, \mathrm{n}=$ 8).

SEM studies show that the antennae differ greatly in the number and types of sensilla present on their surface (Fig. 12 for a representation, Fig. 13A). Several distinct types of sensilla revealed in this study are described below [double- and single-walled wall pore sensilla, following the terminology of Altner (1977) and Steinbrecht (1997)].
Single-walled wall pore (sw-wp) sensilla (Figs 14A-B): These large sensilla are found mainly on the most distal antennomere (11th) and in smaller numbers on the 10th antennomere. Characteristic features are a blunt tip and a deflection towards the antennal tip (Fig. 14A). Their lengths differ between species, the longer being found on the antennae of the Bryaxis species $(53.28 \mu \mathrm{m} ; \mathrm{n}=10$; $\mathrm{SD}=5.5 \mu \mathrm{m})$ and $P h(45.05 \mu \mathrm{m} ; \mathrm{n}=8 ; \mathrm{SD}=8.4 \mu \mathrm{m})$, and the shorter on the antennae of $B f(32.41 \mu \mathrm{m} ; \mathrm{n}=5$; $\mathrm{SD}=4.7 \mu \mathrm{m})$ and $R l(36.48 \mu \mathrm{m} ; \mathrm{n}=10 ; \mathrm{SD}=1.9 \mu \mathrm{m})$. Only small numbers of this type of sensilla were found. The Bryaxis species have an average of $16(\mathrm{n}=3 ; \mathrm{SD}=$ $0.6 ; B b)$ and $17 \mathrm{sw}$-wp sensilla $(\mathrm{n}=7 ; \mathrm{SD}=0.7 ; B p)$. The larger species tend to have greater numbers of slightly less conspicuous sw-wp sensilla: $23(\mathrm{n}=3$; $\mathrm{SD}=0.6)$ in $B f, 39(\mathrm{n}=3 ; \mathrm{SD}=1)$ in $R l$, and $48(\mathrm{n}=4 ; \mathrm{SD}=1.2)$ in $P h$. $B f$ and $R l$ have a crescent-shaped aggregation of 7 sw-wp sensilla on the 11th antennomere (Figs 12B, 13B-D; less conspicuous in $R l$ ).

Double-walled wall pore (dw-wp) sensilla (Figs 14A, C): Of conical shape with the distal part featuring
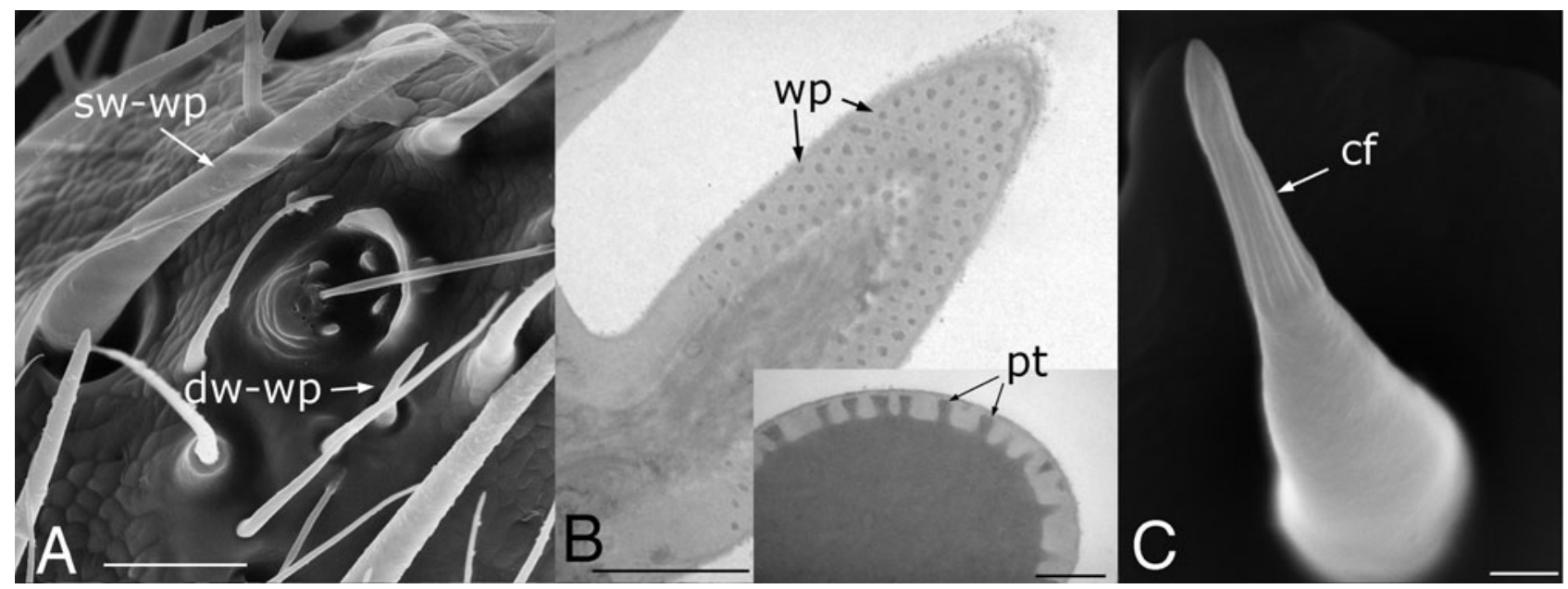

Fig. 14. Sensilla at the antennal tip of Bryaxis puncticollis. (A) SEM-micrograph of both a sw-wp and a dw-wp sensillum (arrows). Bar $=10 \mu \mathrm{m}$. (B) TEM-micrographs of subaxial resp. cross-sections through an sw-wp sensillum in which wall pores are clearly visible. The pore tubules within the wall pores are distinguishable as thin dark lines (arrows; insert). Bar $=2 \mu \mathrm{m}$ (main picture); bar $=0.5 \mu \mathrm{m}$ (inset). (C) SEM-micrograph of a dw-wp sensillum showing cuticular fingers distally. Bar $=1 \mu \mathrm{m}$. Abbreviations: $\mathrm{cf}=$ cuticular fingers, $\mathrm{dw}-\mathrm{wp}=$ double-walled wall pore sensillum, $\mathrm{pt}=$ pore tubules, $\mathrm{sw}$-wp $=$ single-walled wall pore sensillum, $w p=$ wall pore 


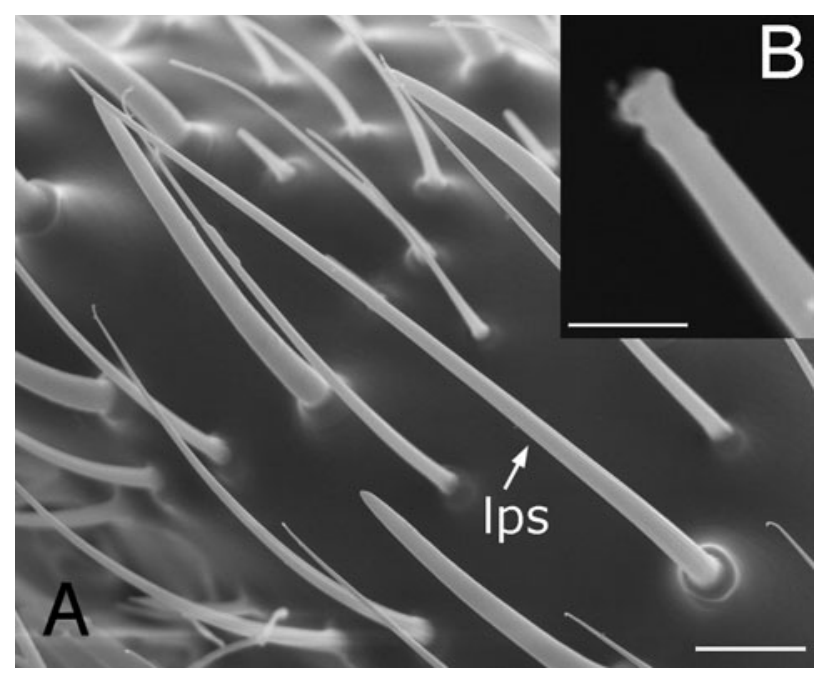

Fig. 15. (A) SEM-micrograph of the long projecting sensilla on the antenna of Rybaxis longicornis. Bar $=10 \mu \mathrm{m}$. (B) Higher magnification of the sensillum tip. Bar $=1 \mu \mathrm{m}$. Abbreviation: lps $=$ long projecting sensillum.

cuticular fingers (Fig. 14C). According to Altner (1977) and Steinbrecht \& Gnatzy (1984) this sensillum lacks pore channels and communicates with its surroundings through so-called spoke channels (Steinbrecht, 1997) that are found between the cuticular finger-like structures. The dw-wp sensilla are characteristically found on the 11th antennomere. They are much smaller than the sw-wp sensilla with an average length of between $8.06 \mu \mathrm{m}$ in $R l$ (n $=5 ; \mathrm{SD}=0.9)$ and $12.3 \mu \mathrm{m}$ in $P h(\mathrm{n}=5 ; \mathrm{SD}=1.6)$. Average numbers vary from only 6 on the antennae of

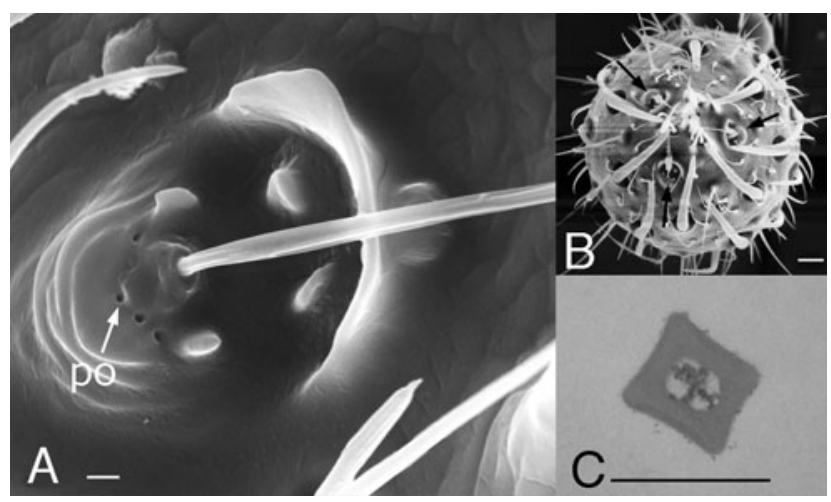

Fig. 16. Trichobothrium-like sensilla on the antenna of Bryaxis puncticollis. (A) SEM-micrograph of a top view of the base of a single sensillum. Bar $=10 \mu \mathrm{m}$. (B) SEM-micrograph of an apical view of the apex of the antenna showing the triangular arrangement of the trichobothrium-like sensilla (arrows). Bar $=10 \mu \mathrm{m}$. (C) TEM-micrograph of a cross-section of a trichobothrium-like sensillum showing the rhombic shape of the cross-section. Bar $=1 \mu \mathrm{m}$. Abbreviation: po $=$ pores.

both Bryaxis species $(\mathrm{n}=10 ; \mathrm{SD}=0.7)$ to 28 in $P h(\mathrm{n}=$ $4 ; \mathrm{SD}=1.7$ ).

Long projecting sensilla (Fig. 15): Originate from a cuticular protuberance. A tubular body is present and the sensillum is much longer than other sensilla. Characteristically it is bent away from the antennal surface and possesses a knob-like ending, visible under the SEM at high magnifications $(\sim 70,000 \times$, Fig. $15 \mathrm{~B})$. The average lengths vary from about $54 \mu \mathrm{m}(B p, B b$ and $P h)$ to $77 \mu \mathrm{m}(B f)$, or even $85 \mu \mathrm{m}(R l)$. There are few of them and the number

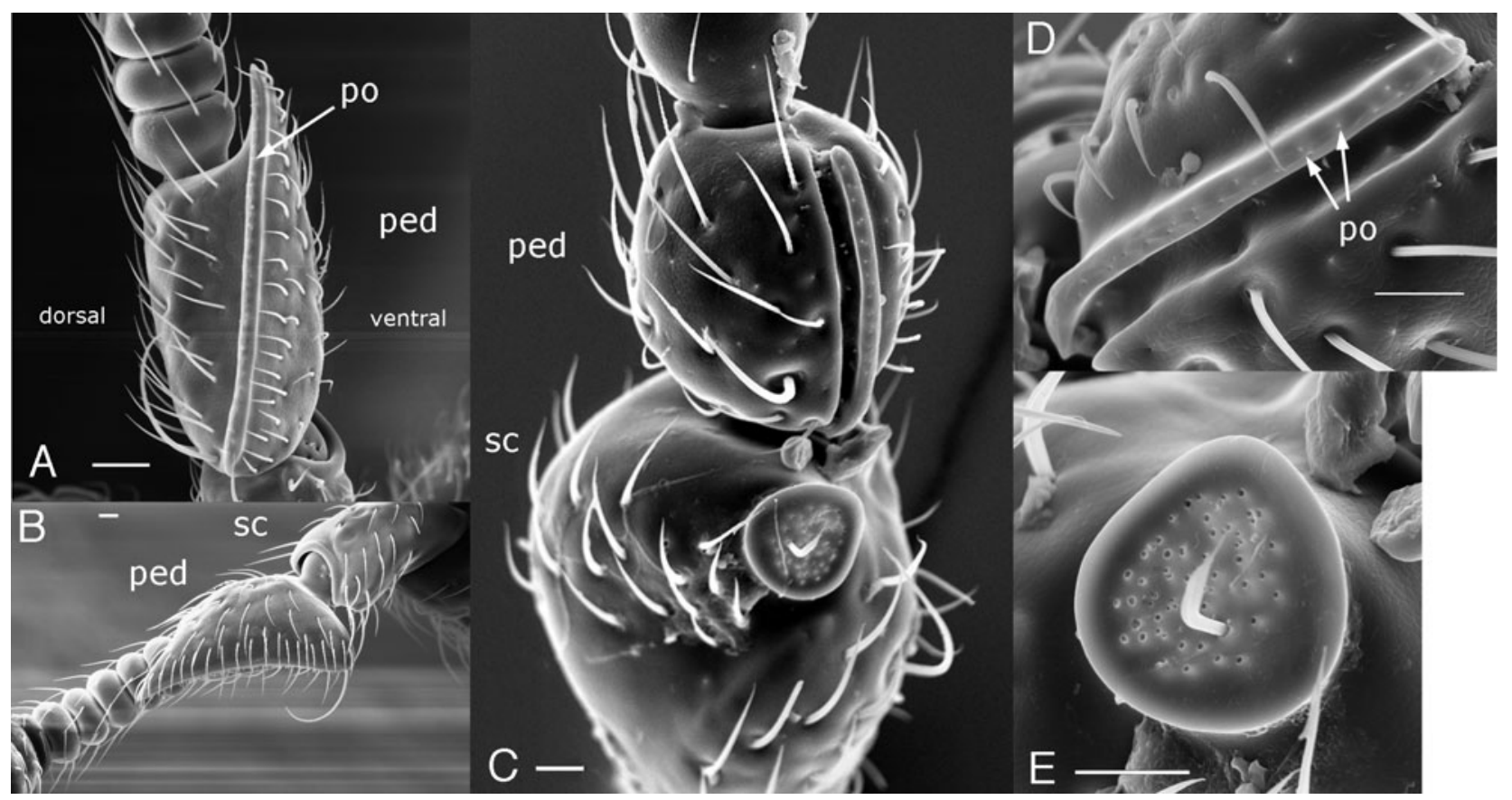

Fig. 17. Peculiar structures on the antennae of selected male pselaphine beetles. (A-B) SEM-micrographs of (A) mesal resp. (B) ventro-mesal aspects of the pedicellus and antenna respectively of Bythinus burrelli. (C-E) SEM-micrographs of scape and pedicel of Bryaxis bulbifer. The pores are clearly visible. (D) Ridge-like modification on the pedicel. (E) Stamp-like modification on the scape. Abbreviations: $\mathrm{sc}=$ scape, ped $=$ pedicel, po $=$ pores. Bars $=10 \mu \mathrm{m}$. 


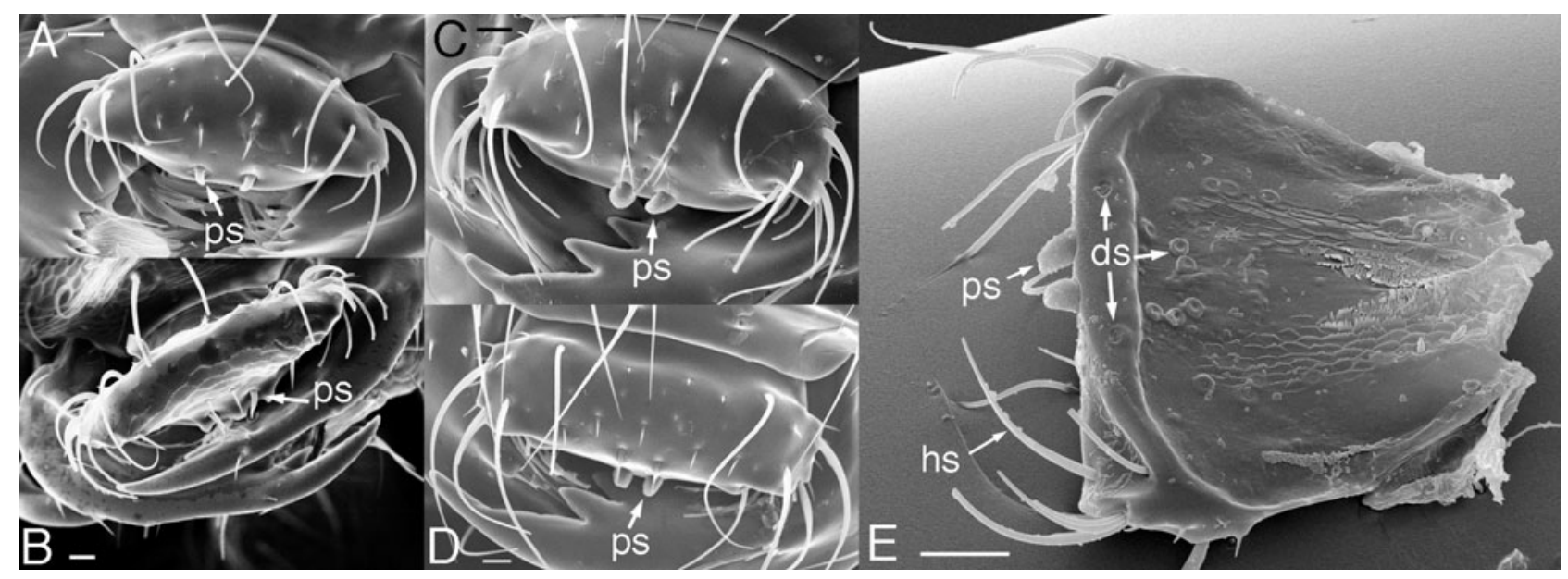

Fig. 18. (A-D) SEM-micrographs of the labrum of (A) Bryaxis puncticollis, (B) Pselaphus heisei, (C) Brachygluta fossulata and (D) Rybaxis longicornis. Bars $=10 \mu \mathrm{m}$. (E) SEM-micrograph of the epipharynx of Brachygluta fossulata. Bar $=20 \mu \mathrm{m}$. Abbreviations: ds = disc-like sensilla (two different types), hs = hair-like sensilla, ps = peg-like sensilla.

was species-specific in our sample, with the largest number (16) in $B p$.

Trichobothria-like sensilla (Fig. 16): Long and extremely fine recognizable by the rhombic shape of the cross-section of their hair shafts and small diameter (Fig. $16 \mathrm{C})$ in ultra-thin sections. There are three of them on the tip of the 11th antennomere in the Bryaxis species. They are arranged in a triangle when viewed apically (Fig. 16B). They arise from a cuticular depression on the 11 th antennomere (Fig. 16A). Several pores are present at their base, which were not investigated further (Fig. 16A).

Peculiar structures on the antennae (Fig. 17): Stampand ridge-like modifications occur on the lower inner side of both the scape and the pedicel in males of $B b$ (Figs $17 \mathrm{C}-\mathrm{E})$, and a crescent-shaped modification on the pedicel of males of Bythinus burrelli (Figs 17A-B). SEM has revealed the presence of pores (Figs 17A, D, E) along the ridges on the pedicels of both species and on top of the stamp-like structure in $B b$ (Fig. 17E).
Furthermore, $R l$ has a distinct broad flattened seta on the tip of its 11th antennomere (Fig. 13D); its function is unknown.

\section{Mouthparts}

The following brief descriptions of the mouthparts of pselaphines generally refer to $B p, B b, B f$ and $P h$ (Table 1).

\section{Clypeo-labrum (Fig. 18):}

Trapeziform and free, i.e., connected with the clypeus by a membrane. The anterior margin features two medial peg-like sensilla (ps in Fig. 18). Several hair-like sensilla of different lengths can be found on its dorsal and lateral sides: the long lateral sensilla are bent toward the medial axis, so that they come in contact with the prey seized by the mandibles. The epipharynx (investigated in $B f$ only) has several disc-like sensilla and two rows of medially directed scales or trichomes (Fig. 18E).

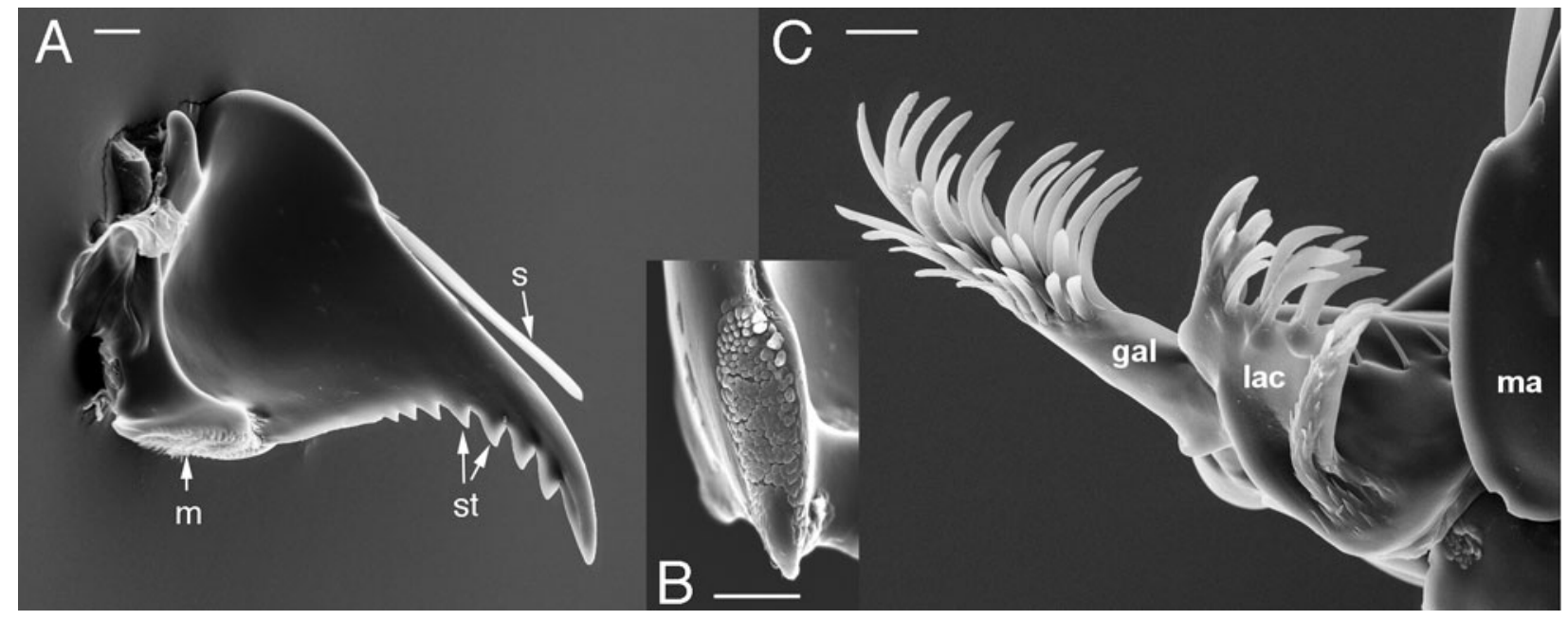

Fig. 19. SEM-micrographs of selected mouthparts of Bryaxis puncticollis. (A) Dorsal aspect of the left mandible. (B) Mesal aspect of the mola. (C) SEM-micrograph of the left maxilla. Bars $=10 \mu \mathrm{m}$. Abbreviations: gal $=$ galea, lac $=$ lacinia, $\mathrm{ma}=$ mandible, $\mathrm{m}=$ mola, $\mathrm{s}=$ sensillum, $\mathrm{st}=$ subapical teeth. 


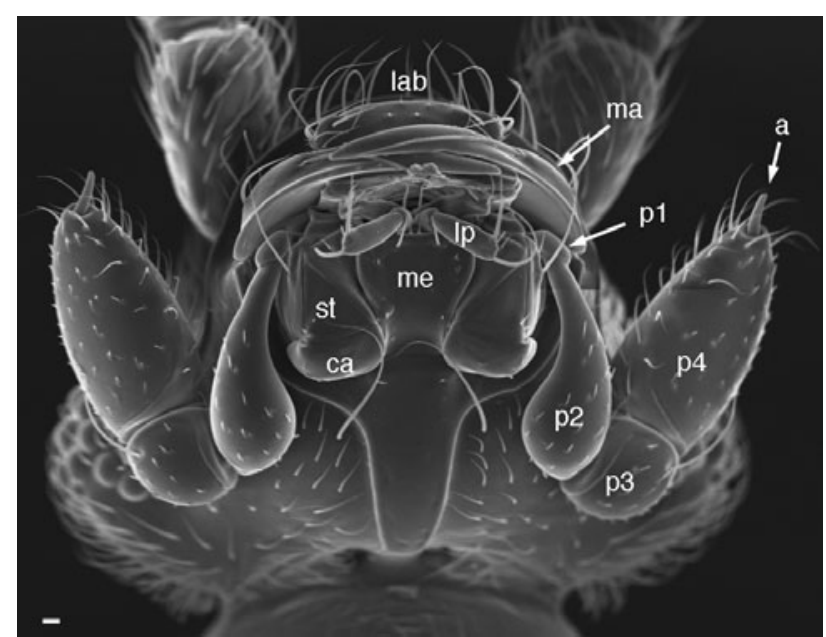

Fig. 20. SEM photograph of the ventral aspect of the head of Brachygluta fossulata. Overview of the mouthparts. Bar $=10$ $\mu \mathrm{m}$. Abbreviations: $\mathrm{a}=$ appendage $, \mathrm{ca}=\mathrm{cardo}, \mathrm{lab}=$ labrum, $\mathrm{lp}$ $=$ labial palpus, $\mathrm{ma}=$ mandible, $\mathrm{me}=$ mentum, $\mathrm{p} 1-\mathrm{p} 4=$ maxillary palpomeres $1-4, \mathrm{st}=$ stipes.
Mandibles (Figs 19A-B):

More or less symmetrical. The apex is simple (unidentate) and several subapical teeth are present (st in Fig. 19A). A prostheca is lacking. The mola is distinct and firmly united to the rest of the mandible. The mola differs in size from well-developed in the Bryaxis species to reduced in $P h$. It has small nipple-like grinding cones (Fig. 19B) on its medial surface. The mandible lengths, measured from the abductor to the tip of the mandible, vary from $0.137 \mathrm{~mm}$ in the Bryaxis species $(\mathrm{n}=13 ; \mathrm{SD}=$ $0.01 \mathrm{~mm})$ to $0.167 \mathrm{~mm}$ in $B f(\mathrm{n}=3 ; \mathrm{SD}=0.01 \mathrm{~mm})$ and $0.207 \mathrm{~mm}$ in $R l(\mathrm{n}=1)$. Electron-micrographic images of the $B p$ mandibles have revealed the presence of a single sensillum on the outer margin ( $\mathrm{s}$ in Fig. 19A). It is particularly conspicuous and long (up to $70 \mu \mathrm{m}$ ), and laterally flattened. The sensilla present on the mandibles of the other species (partly visible in Figs 18B-D) are inserted on the dorsal side and are less distinct and often much smaller and thinner ( $P h$ has several short sensilla). An interaction with other mouthparts has not been observed, and the sensillum is usually positioned relatively close against the mandible. Its function is unknown.

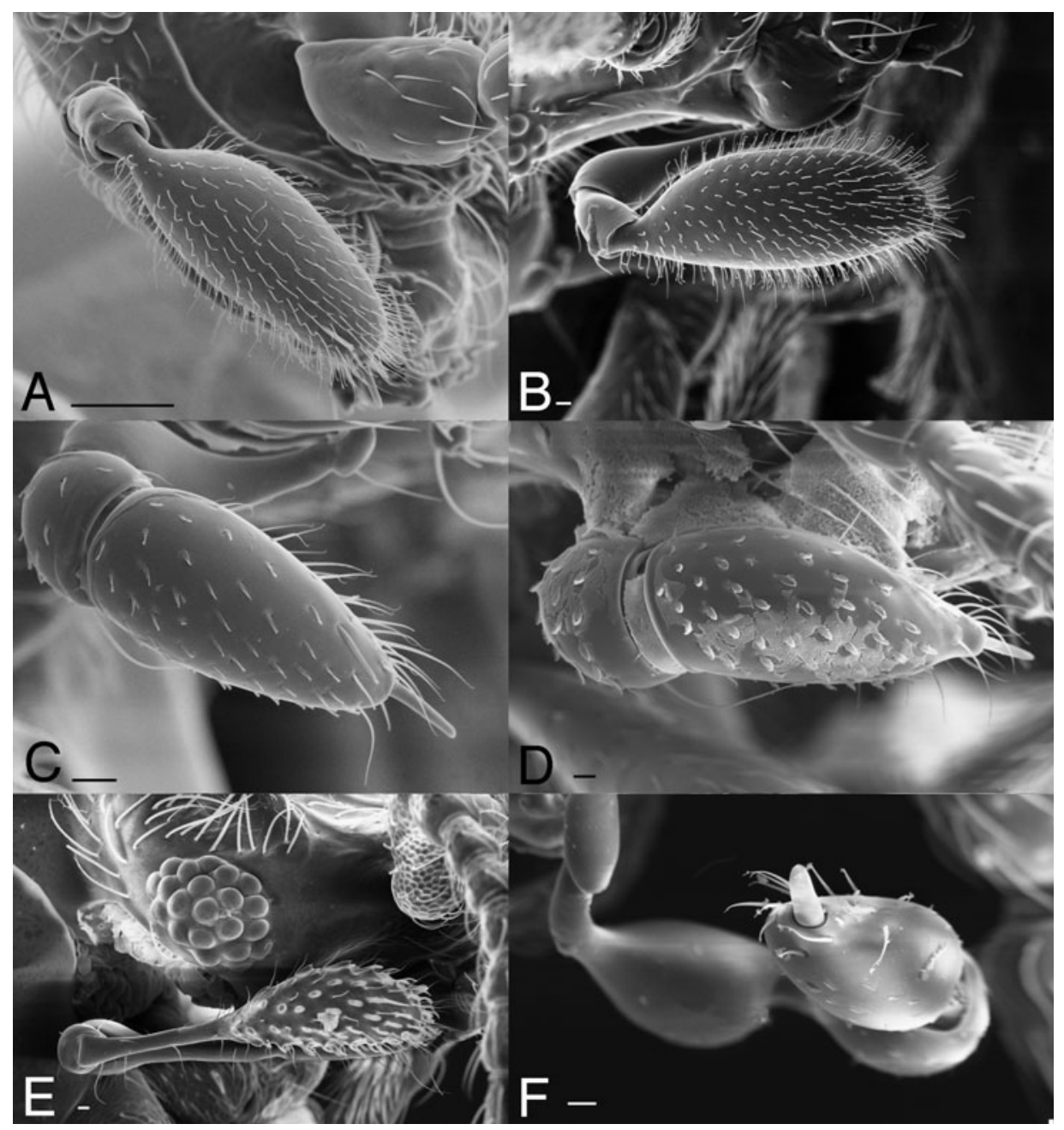

Fig. 21. SEM-micrographs of the maxillary palps of Pselaphinae. The enlarged fourth palpomere and the appendix at its tip is clearly visible. (A) Bryaxis puncticollis; bar $=100 \mu \mathrm{m}$; (B) Bryaxis bulbifer; bar $=10 \mu \mathrm{m}$; (C) Brachygluta fossulata; bar $=10 \mu \mathrm{m}$; (D) Rybaxis longicornis; bar $=10 \mu \mathrm{m}$; (E) Pselaphus heisei; bar $=10 \mu \mathrm{m}$; (F) Tyrus mucronatus; bar $=10 \mu \mathrm{m}$. 


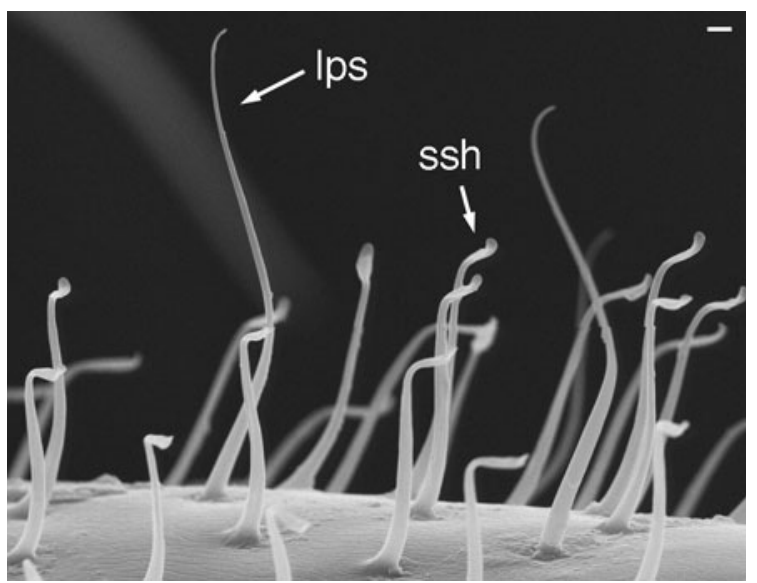

Fig. 22. SEM-photograph of the hair-like structures on the fourth maxillary palpomere of Bryaxis puncticollis. Bar $=1 \mu \mathrm{m}$. Abbreviations: $\mathrm{ssh}=$ spoon-shaped hairs, $\mathrm{lps}=$ long projecting sensilla.

\section{Maxillae (Fig. 19C):}

The cardo is transverse. The stipes is subdivided into basi- and mediostipes, the latter forming the base of both the galea and lacinia. The apices of both are differentiated into mesal brush-like arrays of curved hair-like trichomes (Fig. 19C). The maxillary palps are four-segmented (Fig. 20). The external appearance of the palpomeres is at least genus-specific (Fig. 21). The first palpomere is small (only $P h$ beetles have a strongly elongated first palpomere), the second relatively long and the third short. The fourth palpomere is generally large and varies greatly in appearance between species (Fig. 21).

Both Bryaxis species seem to capture their prey with the help of their maxillary palps. SEM analyses of their fourth palpomere have shown that the dominant type of setae resembles the adhesive structures that are often found on insect tarsi, with the distal parts being spoonshaped (ssh in Fig. 22). The fourth palpomere of $B p$ bears on average 356 (female, $n=4, S D=14$ ) and 441 (male, $n$ $=3, \mathrm{SD}=57$ ), respectively, of these setae. Semi-thin sections of the maxillary palps have revealed the presence of glandular structures (Fig. 23). The outlet was not visible but is possibly situated on the apical part of the spoonshaped hairs, thus supporting the hypothesis that the bee-

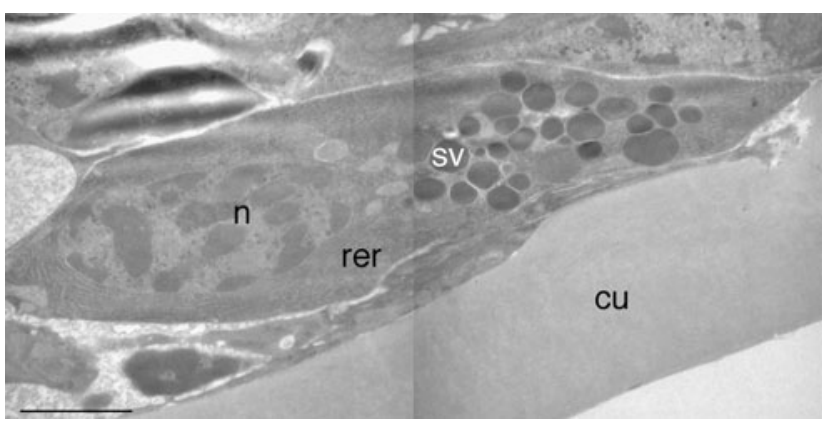

Fig. 23. TEM-micrograph of glandular structures within the left maxillary palp of Bryaxis bulbifer. The secretory vesicles are clearly visible. $\mathrm{Bar}=2 \mu \mathrm{m}$. Abbreviations: $\mathrm{cu}=$ cuticula, $\mathrm{n}$ $=$ nucleus, rer $=$ rough endoplasmatic reticulum, $\mathbf{s v}=$ secretion vesicles.

tles capture their prey by means of the adhesive surface of their palps. Additionally, another type of sensilla was found (lps in Fig. 22), which resemble the long projecting sensilla on the antennae.

A common peculiarity of pselaphine maxillary palps is a segment-like appendage at the tip of the fourth palpomere (Newton \& Thayer, 1995; Fig. 24). This appendage measures $25-35 \mu \mathrm{m}$ in length and ca. $5 \mu \mathrm{m}$ in diameter, and is inserted either in a cuticular depression or on a cuticular socket $(P h)$. The distal part of this appendage features longitudinal striae, which only become visible at high magnification $(7,500 \times)$. The apex is oblique (Fig. 24B) and transmission electron micrographs reveal several cuticular cavities and pore tubules in the cuticle on the slanting mesal side (Fig. 24C). The space between two cavities is filled with small, almost rectangular, cuticular structures, which are separated by small interstices (Fig. 24C). The depth of these cavities varies between 400 and $800 \mathrm{~nm}$. Receptor lymph cavities are visible further proximally, as are several dendrites inside the appendage (Fig 23D). These originate in the fourth palpomere and extend into the appendage, thus indicating its sensory function. A tubular body, which is characteristic of mechanosensilla, was not observed.

\section{Labium (Fig. 25):}

The mentum is large and plate-like and separates the maxillae (Fig. 20). The palps are three-segmented, with

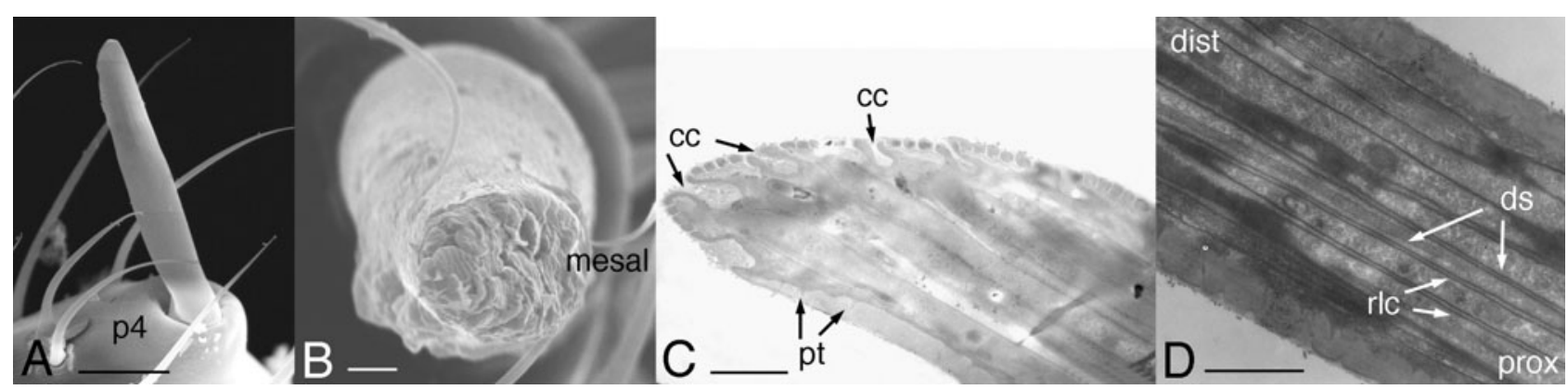

Fig. 24. Ultrastructure of the appendage of the fourth palpomere. (A) SEM-micrograph (Rybaxis longicornis). Bar $=10 \mu \mathrm{m}$. (B) Higher magnification of the apex of the appendage (Bryaxis puncticollis). Bar $=1 \mu \mathrm{m}$. (C-D) TEM-micrographs of longitudinal sections through the appendage (Bryaxis puncticollis). Bars $=1 \mu \mathrm{m}$. Abbreviations: $\mathrm{cc}=$ cuticular cavities, dist $=$ distal, $\mathrm{ds}=\mathrm{dendritic}$ sheaths, $\mathrm{p} 4=$ fourth maxillary palpomere, $\mathrm{prox}=$ proximal, $\mathrm{pt}=$ pore tubules, $\mathrm{rlc}=$ receptor lymph cavities. 


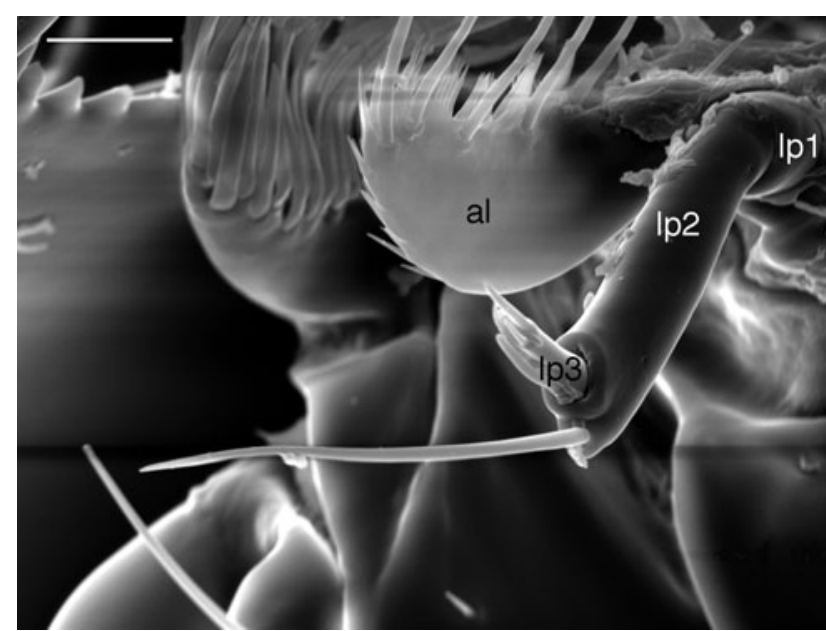

Fig. 25. SEM-micrograph of the right labial palpus of Bryaxis puncticollis. Bar $=10 \mu \mathrm{m}$. Abbreviations: al $=$ apical lobe, $1 \mathrm{p}$ $1-3=$ labial palpomere $1-3$.

the last palpomere sensillum-like (Fig. 25). At its tip the prementum bears prominent apical lobes with a fringe of stout bristles and trichomes (al in Fig. 25). These lobes result from the fusion of the glossa and paraglossa forming a synglossa (Nomura, 1991).

\section{DISCUSSION}

All the species investigated in this study are distributed throughout most of Europe (Besuchet, 1974), with all but Tyrus mucronatus living in grass- and leaf-litter, and in moss growing close to waterbodies and bogs. Tyrus mucronatus live under the bark of dead trees, a habitat where only a small number of species of the subfamily are found.

Pselaphines (more than 9000 described species worldwide) are generally predacious as larvae and adults (Chandler, 2001; Thayer, 2005), the commonest feeding mode among staphylinids (Thayer, 2005). Pselaphines were initially reported to feed on earthworms, insect larvae, small flies and especially mites (Park, 1932, 1933, 1942, 1947a, b; Pearce, 1957), whereas in later studies Collembola were used as the main prey (De Marzo, 1985, 1986, 1988; De Marzo \& Vit, 1982; Engelmann, 1956). Other potential prey animals (mites, ant larvae and Drosophila larvae) were used in this study, but rejected or only reluctantly ingested. However, all of the beetles eagerly preyed upon Collembola (Entomobryidae, whereas the isotomid Folsomia was rejected). Therefore, the collembolan Heteromurus nitidus was used in the prey-capture experiments. Hence, recorded here is the performance of the different beetle species when attempting to catch a rather elusive prey. They might perform differently on other prey types encountered in situations different from those in our laboratory experiments.

Park (1932, 1933, 1947a) worked especially on those species facultatively associated with ants, focused on their feeding behaviour but did not describe their method of capturing prey, possibly because ant larvae and mites are easy to locate and not elusive. Park (1947b) includes a short note indicating that free-living pselaphines mainly feed on mites, which after capture they press to the ground using their fore tarsi. De Marzo \& Vit (1982) report Batrisodes occulatus "trying to catch Collembola with their mandibles", and that fragments of Collembola were found in the intestines. A short account of the preycapture behaviour of Pselaphus parvus larvae is given by De Marzo (1988), who reports that they capture their prey by means of protrusible viscous head organs, with the viscous secretion originating from glands in the head (De Marzo, 1988). According to DeMarzo $(1985,1988)$, this structure is found in all investigated pselaphine larvae; however, it is absent in larvae of Faronitae (Newton, 1991). The most detailed description of the prey-capture in adult Pselaphinae to date is given by Engelmann (1956).

\section{Detection of prey}

The pselaphine beetles studied have relatively reduced eyes, with only a few convex ommatidia. The presence of large numbers of screening pigment granules between the ommatidia is found only in scattered taxa among Coleoptera, and within Staphyliniformia only in Micropeplinae and some Scydmenidae (Caveney, 1986). The Semper cells are probably the remains of a crystal cone (cf. Meyer-Rochow, 1999). The reduced eyes and the lack of a crystal cone are indicative of a life in habitats where light intensities are low (Lawrence \& Britton, 1991), such as litter and rotting logs. These structures clearly suggest that the beetles are not visual hunters. Nonetheless, they respond to light, possibly even ultraviolet light, since many species in tropical and some in temperate regions are collected at ultraviolet lights (Wolda \& Chandler, 1996). Our observations suggest that Brachygluta fossulata, Rybaxis longicornis, and Tyrus mucronatus, which have a higher number of ommatidia than other species, might be able to perceive and follow the movement of their prey visually. The higher number of ommatidia in the males of Bryaxis puncticollis is presumably advantageous when searching for females and a rather common sexual dimorphism known from a number of Pselaphinae (Chandler, 2001; Jeannel, 1950).

In accordance with their poor visual capabilities, tactile and chemical cues seem to play a principal role in prey detection and several types of sensilla may be involved. Of special importance in the search for prey are the antennae, which have a wide range and multitude of sensilla (much more so than on the rest of the body). In the species studied $42-50 \%$ of the antennal sensilla were concentrated on the terminal antennomere (Figs 10, 12). The structural peculiarities of the antennae of Bryaxis bulbifer and Bythinus burrelli are obviously related to mating, as they occur only in males. These structures are rarely located on scapus and pedicel in Pselaphinae, but almost always on the flagellomeres (Chandler, 2001). Sensilla described as single- and double-walled wall pore sensilla have an olfactory function (cf. Altner, 1977; Steinbrecht \& Gnatzy, 1984) in other insects. The position of the olfactory sensilla at the apex of the antennae allows the assessment of the direction of the source of olfactory cues (Skilbeck \& Anderson, 1996), and the constant move- 
ment of the antennae promotes the perception of chemical cues according to phasic receptor physiology (e.g., Zacharuk, 1985). The antennal tips of the Bryaxis species are additionally equipped with specific trichobothria-like sensilla (Fig. 16). They probably function as receptors of air vibrations. Brachygluta fossulata, Rybaxis longicornis and Pselaphus heisei lack this type of sensilla. Notwithstanding, these species were capable of identifying prey, even without mechanical contact.

Like the antennal movements, the maxillary palps, vibrated in Bryaxis puncticollis and Tyrus mucronatus, also seem to be involved in the perception of olfactory cues. This is also described for Batrisodes globosus, Euplectus sp. and Bibloplectus sp. (Engelmann, 1956). Testing the ground with the maxillary palps as observed in Pselaphus heisei can be interpreted in terms of searching for gustatory chemical cues of prey.

The fourth maxillary palpomere has a characteristic appendage (a in Fig. 20; Figs 21, 24) at its distal end, a synapomorphy for the subfamily (Newton \& Thayer, 1995). Thayer (2005) describes this appendage of the maxillary palps as an "unsclerotized digitiform segmentlike appendage", whereas Jeannel (1950) and Pearce (1957) consider it to be a fifth palpomere. Others have identified it as an ordinary sensillum. The origin of this structure remains unclear. As it has several cuticular sheaths it appears to be a compound sensillum formed by the fusion of several sensilla. That it has a sensory function can be deduced from the dendrites and dendritic sheaths within the appendage (Fig. 24). The morphology suggests a contact chemoreceptor.

The long projecting sensilla (Fig. 15) on the antennae seem to have a bimodal mechanoreceptive function. They are characterized by their shape (usually S-curved), with the most distal part being bent away from the antennal surface (G. Alberti, pers. comm.). This type of sensilla lacks lateral wall pores. Instead they have a single pore at the apex (cf. Ozaki \& Tominaga, 1999), which suggests a gustatory function. We have found similar sensilla on the fourth maxillary palpomere (between those with spoonlike apices, Fig. 22), which might have the same modalities. The many small, thin sensilla on the antennae are probably simple mechanoreceptors for tactile perception. Tactile contact (generally with the antennae) seems to be necessary to induce preparation for the predatory strike in at least Bryaxis puncticollis, Rybaxis longicornis and Tyrus mucronatus.

\section{Predatory strike}

All the beetles investigated slightly touch their prey during the preparation phase prior to the strike, probably in order to ascertain its exact location and identify it as prey using gustatory sensilla. These contacts are usually so gentle that they do not initiate the escape mechanism of the Collembola, and therefore the beetles do not have to strike faster than the prey can initiate the escape (in Collembola about $26 \mathrm{~ms}$ subsequent to the stimulus, Bauer, 1978).

In all the pselaphines studied there occurred an upward movement of the body prior to the strike (Fig. 3A). This might function to accelerate the strike, so that the maxillary palps of the Bryaxis species hit the prey at a relatively high velocity. If any adhesive secretion is involved, this would result in a better adhesion to the surface of the prey (Betz \& Kölsch, 2004). The role of the palps of Pselaphus heisei in prey-capture is not easy to determine, since ultrastructural examinations revealed no evidence of an adhesive surface. Hence, in this case the prey might simply be captured by entanglement among the massive setae on the maxillary palps (Fig. 21E).

The broad conclusion of this limited comparative study is that the prey-capture behaviour seems to be similar within certain tribes of Pselaphinae (classification into tribes according to Löbl \& Besuchet, 2004, and Newton $\&$ Chandler, 1989). The prey-capture behaviour in all the species studied is substantially different from the relatively simple behaviour described for Batrisodes globosus (tribe Batrisini), Euplectus sp. (tribe Euplectini), and Bibloplectus sp. (tribe Trichonychini) by Engelmann (1956). In these three species the beetles briefly stop their forward movement, then lunge forward and grasp the collembolan with their mouthparts. Of the species investigated in the present study, the behaviour of the members of the Brachyglutini is most similar.

Other behavioural features and structures seem to be more derived compared with this general pattern. (1) The presumably sticky maxillary palps of the Bryaxis species (tribe Bythinini) are a specific prey-capture device not previously described. (2) The behaviour of Tyrus mucronatus beetles seems to resemble that of Cedius spinosus (both species belonging to the tribe Tyrini) described by Engelmann (1956). The latter species slowly approaches the prey, "steadies itself upon its meso- and metathoracic legs, and rears up slightly" before seizing the prey (Engelmann, 1956). Hence, both of these species capture their prey by means of their forelegs, sandwiching it between the femur and tibia, an action supported by the mouthparts in Cedius spinosus (Engelmann, 1956). Engelmann (1956) observed similar prey-capture behaviour in Tmesiphorus costalis (tribe Tmesiphorini, closely related to Tyrini). All three species have specific morphologically modified forelegs, which supposedly improve their predatory strike, i.e., (i) spines on the femur and tibia in Cedius spinosus, (ii) trochantero-femoral spines and ridges in Tyrus mucronatus and (iii) stiff brushes of setae on the femur and tibia in Tmesiphorus costalis. Such prey-capture behaviour employing raptorial fore legs appears to be rather unique within the Coleoptera and has only recently been described for two other groups of staphylinids, i.e., the genus Philonthus subgenus Onychophilonthus Neresheimer \& Wagner (Betz \& Mumm, 2001) and Nordus fungicola (Sharp) (Chatzimanolis, 2003).

Complex preparation behaviour prior to the strike and directing the prey towards the mandibles with the help of the antennae was not recorded for Cedius and Tmesiphorus by Engelmann (1956), possibly because of the poor technical facilities available at that time. 


\section{Prey-handling}

Another previously undescribed behaviour in pselaphines is prey-handling. Only Engelmann (1956) records that a Bibloplectus beetle held down a large isotomid collembolan with its fore tarsi. The specific behaviour described in the present study, which involves the manipulation of the position of the prey in the mouthparts, might be a special adaptation for catching elusive prey such as Collembola.

The maximum prey size manageable by a beetle depends on the prey's combativeness and the predator's ability to hold and subdue it. As far as prey size is concerned, the two Bryaxis species, Brachygluta fossulata and Pselaphus heisei were similar, i.e., they preferred small to large prey (Fig. 6). However, these species differed significantly in their general prey-capture success (Fig. 7). The absolute length of their antennae and their pattern of movement did not seem to be related to preycapture success. Apart from its lower strike velocity, the reason for the lower success in Pselaphus heisei might be the lower number of mechanoreceptors on the antennae, possibly resulting in a less accurate location of the prey and an imprecise strike. Moreover, Pselaphus heisei has relatively short mandibles (ratio mandible length/body length, 0.086), which could also decrease its capture success. The difference in the capture success of the two Bryaxis species might be caused by the different adhesive properties of the maxillary palps.

Based on the behavioural observations on one individual, Tyrus mucronatus seems to be an extremely effective predator. Its complex behaviour prior to the strike permits accurate location of the prey, and its predatory legs allow the strike to be especially precise and successful.

\section{CONCLUSIONS}

This study provides new information on the behaviour and morphology of a hitherto largely neglected group, the Pselaphinae. These data improve our knowledge of the prey-capture behaviour of this very diverse group of beetles and should spur further comparative behavioural analyses.

The pselaphines studied differ significantly in the array of sensilla on their sensory organs. In particular, the differences in the numbers and types of sensilla on the antennal tip might correspond to differences in preyfinding success. Pselaphines do not seem to be visual hunters, but rather employ chemical and mechanical cues, which is to be expected of litter-dwelling organisms.

Although they vary in size and have different sized mandibles, all of them prefer the smallest prey-size classes offered. Notwithstanding, the beetles differ in their specific prey-capture strategies. These might be tribe-specific and are highly elaborate in some species, leading to increased prey-capture success, for instance the use of sticky maxillary palps (e.g., Bryaxis bulbifer) or raptorial legs (Tyrus mucronatus), or certain behavioural patterns prior to the strike. Beetles of other species simply use their mandibles, probably the ancestral method of capturing prey.
Because of their great ecological and morphological diversity, this subfamily seems to have great potential for future integrative studies on the evolution of functional and ecological diversity in soil organisms.

ACKNOWLEDGEMENTS. Our thanks are extended to T. Bauer who supervised this work, to A. Thomas and F. AntonErxleben for technical assistance with the morphological work (all at the University of Kiel, Germany), to G. Alberti (University of Greifswald, Germany) who shared his expertise on the structure and function of arthropod sensilla, and to A. Solodovnikov (Zoological Museum Copenhagen, Denmark) for helpful comments on a previous version of this manuscript. T. Jones and an anonymous language editor corrected the English of the manuscript.

\section{REFERENCES}

AltNer H. 1977: Insect sensillum specificity and structure: an approach to a new typology. In LeMagnen J. \& MacLeod P. (eds): Olfaction and Taste. Vol. VI. Information Retrieval, London, pp. 295-303.

BAUER T. 1978: The behavioural strategy used by imago and larva of Notiophilus biguttatus F. (Coleoptera, Carabidae) in hunting Collembola. On the evolution of behaviour in carabid beetles. Fieldstat. Rees-Grietherb. Univ. Cologne 1978 (Sept): 10-13.

Besuchet C. 1974: 24. Familie: Pselaphidae. In Freude H., Harde K.W. \& Lohse G.A. (eds): Die Käfer Mitteleuropas 5. Staphylinidae II. Göcke \& Evers, Krefeld, pp. 305-362.

Besuchet C. 1989: 24. Familie: Pselaphidae. In Lohse G.A. \& Lucht W.H. (eds): Die Käfer Mitteleuropas. 1. Supplementband mit Katalogteil. Göcke \& Evers, Krefeld, pp. 240-243.

Betz O. \& Kölsch G. 2004: The role of adhesion in prey capture and predator defence in arthropods. Arthr. Struct. Dev. 33: $3-30$.

Betz O. \& Mumm R. 2001: The predatory legs of Philonthus marginatus (Coleoptera, Staphylinidae): functional morphology and tarsal ultrastructure. Arthr. Struct. Dev. 30: 77-97.

CAmmaerts R. 1991: Interactions comportementales entre la fourmi Lasius flavus (Formicidae) et le coléoptère myrmécophile Claviger testaceus (Pselaphidae). Bull. Ann. Soc. R. Belge Entomol. 127: 271-307.

CAVENEY S. 1986: The phylogenetic significance of ommatidium structure in the compound eyes of polyphagan beetles. Can. J. Zool. 64: 1787-1819.

ChANDLER D.S. 2001: Biology, morphology and systematics of the ant-like litter beetle genera of Australia (Coleoptera: Staphylinidae: Pselaphinae). Memoirs on Entomology, International 15. Associated Publishers, Gainesville, FL, 560 pp.

Chatzimanolis S. 2003: Natural history and behavior of Nordus fungicola (Sharp) (Coleoptera: Staphylinidae). Ann. Entomol. Soc. Am. 96: 225-230.

De Marzo L. 1985: Organi erettili e ghiandole tegumentali specializzate nelle larve di Batrisodes oculatus Aubé: studio morfo-istologico (Coleoptera, Pselaphidae). Entomologica (Bari) 20: 125-146.

De Marzo L. 1986: Osservazioni etologiche sulle larve di Batrisodes oculatus Aubé (Coeoptera, Pselaphidae). Frust. Entomol. (N.S.) 7-8: 501-506.

De Marzo L. 1988: Comportamento predatorio nelle larve di Pselaphus heisei Herbst (Coleoptera, Pselaphidae). In: Atti del XV Congresso Nazionale Italiano di Entomologia 1988, L'Aquila, pp. 817-824. 
De Marzo L. \& Vit S. 1982: Note sulla presenza di Batrisodes oculatus Aubé (Coleoptera, Pselaphidae) in una grotta di Puglia. Entomologica (Bari) 17: 149-162.

ENGELMANN M.D. 1956: Observations on the feeding behavior of several pselaphid beetles. Entomol. News 67: 19-24.

Hansen M., Pedersen J. \& Pritzl G. 1999: Records of beetles from Denmark, 1998 (Coleoptera). Entomol. Medd. 67: 71-102 [in Danish, English abstract].

Jeannel R. 1950: Coléoptères Psélaphides. Faune de France 53: $1-421$.

LAwrence J.F. \& BRItTon E.B. 1991: Coleoptera. In CSIRO (ed.): The Insects of Australia. A Textbook for Students and Research Workers. 2nd ed. Vol. II. Cornell University Press Ithaca, New York, pp. 543-683.

LÖBL I. \& BESUCHET C. 2004: Family Staphylinidae: Pselaphinae. In Löbl I. \& Smetana A. (eds.): Catalogue of Palaearctic Coleoptera. Vol. 2: Hydrophiloidea-Histeroidea - Staphylinoidea. Apollo Books, Steenstrup, pp. 272-329.

MeYer-Rochow V.B. 1999: Compound eye: Circadian rhythmicity, illumination, and obscurity. In Eguchi E. \& Tominaga Y. (eds): Atlas of Arthropod Sensory Receptors. Springer, Tokyo, pp. 97-124.

Newton A.F. 1991: Pselaphidae (Staphylinoidea). In Stehr F.W. (ed.): Immature Insects. Vol. 2. Kendall/Hunt, Dubuque, Iowa, pp. 353-355.

Newton A.F. \& Chandler D.S. 1989: World catalog of the genera of Pselaphidae, Coleoptera. Field. Zool. (N.S.) 53: $1-93$.

Newton A.F. \& Thayer M.K. 1995: Protopselaphinae new subfamily for Protopselaphus new genus from Malaysia, with a phylogenetic analysis and review of the Omaliine group of Staphylinidae including Pselaphidae (Coleoptera). In Pakaluk J. \& Slipinski S.A. (eds): Biology, Phylogeny and Classification of Coleoptera: Papers Celebrating the 80th Birthday of Roy A. Crowson. Muzeum i Instytut Zoologii PAN, Warszawa, pp. 219-320.

NomuRa A.S. 1991: Systematic study on the genus Batrisoplisus and its allied genera from Japan (Coleoptera, Pselaphidae). Esakia 30: 1-462.

OzaKi M. \& Tominaga Y. 1999: Contact chemoreceptors. In Eguchi E. \& Tominaga Y. (eds): Atlas of Arthropod Sensory Receptors. Springer, Tokyo, pp. 143-154.

PARK O. 1932: The food of Batrisodes globosus (Lec.) (Coleop.: Pselaphidae). J. N. Y. Entomol. Soc. 40: 377-378.

PARK O. 1933: The food and habits of Temesiphorus costalis Lec. (Coleop.: Pselaphidae). Entomol. News 44: 149-151.

PArk O. 1942: A study in Neotropical Pselaphidae. Northwest. Univ. Stud. Biol. Sci. Med. 1: x 403 pp.
PArK O. 1947a: Observations on Batrisodes (Coleoptera: Pselaphidae), with particular reference to the American species east of the Rocky Mountains. Bull. Chicago Acad. Sci. 8(3): 45-131.

PARK O. 1947b: The pselaphid at home and abroad. Sci. Mon. 65: 27-42.

Pearce E.J. 1957: Coleoptera (Pselaphidae). In: Handbook for the Identification of British Insects. Vol. IV (9). Royal Entomological Society, London, $32 \mathrm{pp}$.

PogGi F. 1990: Osservazioni sulla copula in alcune specie di Pselaphidae. Boll. Soc. Entomol. Ital. 122: 123-127.

ReICHLE D.E. 1967: The temperature and humidity relations of some bog pselaphid beetles. Ecology 48: 208-215.

Robinson D.G., Ehlers U., Herken R., Hermann B., Mayer F. \& Schürmann F.-W. 1985: Präparationsmethodik in der Elektronenmikroskopie. Springer, Berlin, Heidelberg, New York, Tokyo, $280 \mathrm{pp}$.

RohlF F.J. 2004: TpsDig version 1.40. Department of Ecology and Evolution, State University of New York at Stony Brook, Stony Brook. Available at: http://life.bio.sunysb.edu/morph/

Sabella G., Brachat V. \& Bückle C. 1998: Revision of Tychus of dalmatinus group, with description of new taxa (Coleoptera: Pselaphidae). Ann. Soc. Entomol. Fr. 34: 217-244.

Skilbeck C.A. \& ANDERson M. 1996: The ultrastructure, morphology and distribution of sensilla on the antennae of the adult parasitoids Aleochara bilineata Gyll. and Aleochara bipustulata L. (Coleoptera: Staphylinidae). Int. J. Insect Morphol. Embryol. 25: 261-280.

SteINBRECht R.A. 1997: Pore structures in insect olfactory sensilla: a review of data and concepts. Int. J. Insect Morphol. Embryol. 26: 229-245.

Steinbrecht R.A. \& Gnatzy W. 1984: Pheromone receptors in Bombyx mori and Antheraea pernyi - reconstruction of the cellular organization of the sensilla trichodea. Cell Tissue Res. 235: $25-34$.

Thayer M.K. 2005: Staphylinidae. In Beutel R.G. \& Leschen R.A.B. (volume eds): Coleoptera, Vol. I. Morphology and Systematics (Archostemata, Adephaga, Myxophaga, Polyphaga partim). Handbook of Zoology Vol. IV, Arthropoda: Insecta. Part 38. De Gruyter, Berlin, New York, pp. 296-345.

Wolda H. \& ChandLER D.S. 1996: Diversity and seasonality of tropical Pselaphidae and Anthicidae (Coleoptera). Proc. K. Ned. Akad. Wet. 99: 313-333.

ZACHARUK R.Y. 1985: Antennae and sensilla. In Kerkut G.A. \& Gilbert L.I.: Comprehensive Insect Physiology, Biochemistry and Pharmacology. Vol. 6. Pergamon Press, New York, pp. $1-69$.

Received February 1, 2008; revised and accepted July 10, 2008 